\title{
Forming Mechanism of Equilibrium and Non- equilibrium Metallurgical Phases in Dissimilar Materials: Illustrated With Aluminum/steel (Al-Fe) Joints
}

\section{Shun-Li Shang ( $\sim$ sus26@psu.edu )}

Pennsylvania State University

Hui Sun

Pennsylvania State University

\section{Bo Pan}

Pennsylvania State University

\section{Yi Wang}

Pennsylvania State University

\section{Adam M. Krajewski}

Pennsylvania State University

\section{Mihaela Banu}

University of Michigan

\section{Jingjing Li}

Pennsylvania State University

\section{Zi-Kui Liu}

Pennsylvania State University

\section{Research Article}

Keywords: Al-Fe intermetallic compounds, welding, additive manufacturing, density functional theory (DFT) based thermodynamics, phonon calculations, elastic constants

Posted Date: July 28th, 2021

DOl: https://doi.org/10.21203/rs.3.rs-745143/v1

License: (9) (1) This work is licensed under a Creative Commons Attribution 4.0 International License. Read Full License 


\title{
Forming mechanism of equilibrium and non-equilibrium metallurgical phases in dissimilar materials: Illustrated with aluminum/steel (Al-Fe) joints
}

\author{
Shun-Li Shang a, ${ }^{\text {, }}$, Hui Sun ${ }^{\mathrm{a}}$, Bo Pan ${ }^{\mathrm{b}}$, Yi Wang ${ }^{\mathrm{a}}$, Adam M. Krajewski ${ }^{\mathrm{a}}$, Mihaela Banu, ${ }^{\mathrm{c}}$ \\ Jingjing Li ${ }^{\mathrm{b}}, \mathrm{Zi}-\mathrm{Kui} \mathrm{Liu}^{\mathrm{a}}$
}

${ }^{a}$ Department of Materials Science and Engineering, Pennsylvania State University, University Park, PA 16802, USA

b Department of Industrial and Manufacturing Engineering, Pennsylvania State University, University Park, PA 16802, USA

${ }^{\mathrm{c}}$ Department of Mechanical Engineering, University of Michigan, Ann Arbor, MI 48109, USA

*E-mail: sus26@psu.edu 


\section{ABSTRACT:}

Forming metallurgical phases has a critical impact on the performance of dissimilar materials joints. Here, we shed light on the forming mechanism of equilibrium and non-equilibrium intermetallic compounds (IMCs) in the dissimilar aluminum/steel joints with respect to processing history (e.g., the pressure- and temperature-profiles) and chemical composition, where the used knowledge of free energy and atomic diffusion in the Al-Fe system was taken from first-principles phonon calculations and data available in the literature. We found that the metastable while ductile (judged by the presently predicted elastic constants) $\mathrm{Al}_{6} \mathrm{Fe}$ is a pressure $(P)$ favored IMC observed in the processes involving high pressures. The $\mathrm{MoSi}_{2}$-type $\mathrm{Al}_{2} \mathrm{Fe}$ is a brittle and a strong $P$-favored IMC observed at high pressures. The stable, brittle $\eta-\mathrm{Al}_{5} \mathrm{Fe}_{2}$ is the most commonly observed IMC (followed by $\theta-\mathrm{Al}_{13} \mathrm{Fe}_{4}$ ) in almost all processes, such as fusion/solid-state welding and additive manufacturing $(A M)$, since $\eta-\mathrm{Al}_{5} \mathrm{Fe}_{2}$ is temperature-favored, possessing high thermodynamic driving force of formation and the fastest atomic diffusivity among all Al-Fe IMCs. Notably the ductile $\mathrm{AlFe}_{3}$, the less ductile $\mathrm{AlFe}$, and most of the other IMCs can be formed during AM, making AM a superior process to achieve desired IMCs in dissimilar materials. In addition, the unknown configurations of $\mathrm{Al}_{2} \mathrm{Fe}$ and $\mathrm{Al}_{5} \mathrm{Fe}_{2}$ were also examined by machine learning based datamining together with first-principles verifications and structure predictor. All the IMCs, which are not $P$ favored, can be identified using the conventional equilibrium phase diagram and the ScheilGulliver non-equilibrium simulations.

Keywords: Al-Fe intermetallic compounds; welding; additive manufacturing; density functional theory (DFT) based thermodynamics; phonon calculations; elastic constants 


\section{Introduction}

Joining of dissimilar materials has become increasingly important to create lightweight, highperformance, and economic structures applied in various industries, for example, automotive ${ }^{1}$, aerospace $^{2,3}$, marine ${ }^{4}$, and information technology ${ }^{5}$. Specially, joining of aluminum (Al) to steel/iron $(\mathrm{Fe})$ is of eminent technical interest due to the use of two essential engineering materials in the same design ${ }^{1,6}$. It is known that mechanical properties of dissimilar materials are strongly affected by the type, amount/thickness, and morphology of the metallurgical phases formed at the bonding interfaces. For example, the formation of brittle intermetallic compounds (IMCs), such as $\eta-\mathrm{Al}_{5} \mathrm{Fe}_{2}{ }^{7,8}$, is usually detrimental to the performance of dissimilar materials joints owing to the reduction of materials' strength, ductility, and fracture toughness. A great deal of efforts in chemistry and process design is hence required to avoid or reduce their formation in dissimilar materials, demanding fundamental understanding of phase stability of IMCs during various processes, for example, different pressure $(P)$ and temperature $(T)$ profiles under a given chemical composition.

Relevant to the present focus of Al-Fe joints, there are six IMCs shown in the equilibrium Al-Fe phase diagram under external pressure $P=0 \mathrm{GPa}$; see Figure 1 which was modelled by the CALPHAD (calculations of phase diagram) approach by Sundman et al. ${ }^{9}$. It includes the stable IMCs of $\theta-\mathrm{Al}_{13} \mathrm{Fe}_{4}, \eta-\mathrm{Al}_{5} \mathrm{Fe}_{2}, \mathrm{Al}_{2} \mathrm{Fe}, \mathrm{AlFe}$ (in B2 structure), $\mathrm{AlFe}{ }_{3}\left(\mathrm{D}_{3}\right)$, and the metastable $\varepsilon$ $\mathrm{Al}_{8} \mathrm{Fe}_{5}\left(\mathrm{D} 8_{2}\right)$. In addition, the other metastable IMCs include $\mathrm{Al}_{6} \mathrm{Fe}$ and $\mathrm{Al}_{\mathrm{m}} \mathrm{Fe}(4 \leq \mathrm{m} \leq 4.4){ }^{10}$, which are absent in Figure 1. It is believed that the Al-rich IMCs $\left(\mathrm{Al}_{13} \mathrm{Fe}_{4}, \mathrm{Al}_{5} \mathrm{Fe}_{2}\right.$, and $\left.\mathrm{Al}_{2} \mathrm{Fe}\right)$ are brittle and favor crack nucleation in the joints, while the Fe-rich IMCs (i.e., the BCC based AlFe and $\mathrm{AlFe}_{3}$ ) show higher ductility and strength ${ }^{7,8}$. The ductility and brittleness of these IMCs are 
shown in Figure 2 according to Pugh's criterion ${ }^{11,12}$, i.e., the ratio of bulk modulus versus shear modulus $(B / G)$ based on the present first-principles calculations ( $c f$. ., Sec. 2.3). It indicates the ductile $\mathrm{Al}_{6} \mathrm{Fe}, \mathrm{Al}_{5} \mathrm{Fe}_{8}$, and $\mathrm{AlFe}_{3}$; the less ductile $\mathrm{Al}_{13} \mathrm{Fe}_{4}$ and $\mathrm{AlFe}$; and the brittle $\mathrm{Al}_{5} \mathrm{Fe}_{2}$ and $\mathrm{Al}_{2} \mathrm{Fe}$. Table 1 summarizes the Al-Fe IMCs formed in different processes reported in the literature. The metastable, ductile $\mathrm{Al}_{6} \mathrm{Fe}$ was observed in the processes of direct chill casting (example \#1 shown in Table 1) ${ }^{10}$, high-pressure die casting (\#2) ${ }^{13}$, equal channel angular extrusion (\#3) ${ }^{14}$, tungsten inert gas (TIG) welding-brazing (\#4) ${ }^{15}$, and additive manufacturing (AM) via the laser powder bed fusion (\#5) ${ }^{16}$. These observations suggest that $\mathrm{Al}_{6} \mathrm{Fe}$ is an IMC existed at high pressures. Table 1 further depicts that most of the stable and even metastable Al-Fe IMCs were observed in the $\mathrm{AM}$ processes. For example, the $\mathrm{Al}_{6} \mathrm{Fe}, \mathrm{Al}_{13} \mathrm{Fe}_{4}, \mathrm{Al}_{2} \mathrm{Fe}, \mathrm{Al}_{5} \mathrm{Fe}_{2}, \mathrm{AlFe}$, and/or $\mathrm{AlFe}_{3}$ were formed during the processes of laser powder bed fusion ${ }^{16}$, laser cladding ${ }^{17}$, direct energy deposition ${ }^{18}$, laser metal deposition ${ }^{19}$, and/or wire-arc AM ${ }^{20,21}$ (see examples \#5 to \#10 in Table 1). In particular, the ductile (or less brittle) $\mathrm{Al}_{13} \mathrm{Fe}_{4}, \mathrm{AlFe}$, and $\mathrm{AlFe}_{3}{ }^{20-22}$ (examples \#9 to \#11) were observed in the Al-Fe based functional gradient materials fabricated by additive manufacturing. These experiments indicate that $\mathrm{AM}$ is an exceptional process to tailor compositions and in turn the desired IMCs. In the fusion and/or solid-state welding joints, $\mathrm{Al}_{5} \mathrm{Fe}_{2}$ is the most observed IMC (usually adjected to iron/steel) followed by $\mathrm{Al}_{13} \mathrm{Fe}_{4}$ (usually adjacent to Al) processed by, for example, laser welding ${ }^{23-25}$ (see examples \#13 to \#15 in Table 1), frictiontype solid state welding ${ }^{26-34}$ (\#16 to \#24), cold metal transfer fusion welding ${ }^{35}$ (\#25), and double electrode gas metal arc welding ${ }^{36}$ (\#26). The other IMCs such as $\mathrm{Al}_{2} \mathrm{Fe}$ and $\mathrm{AlFe}_{3}$ were also observed in welding processes depended on welding conditions (e.g., energy inputs) ${ }^{7}$; see examples \#14, \#21, and \#22 in Table 1. The same as those in welding processes, $\mathrm{Al}_{5} \mathrm{Fe}_{2}$ (major) and $\mathrm{Al}_{13} \mathrm{Fe}_{4}$ were also observed in immersion tests with solid $\mathrm{Fe}$ and liquid $\mathrm{Al}^{37-39}$ (see examples 
\#27 to \#29 in Table 1), Al-Fe diffusion couples ${ }^{40-42 ~(\# 30 ~ t o ~ \# 32), ~ h i g h-t e m p e r a t u r e ~ r e a c t i v e ~}$ sintering ${ }^{43}(\# 12)$, and aluminized steel ${ }^{44}(\# 33)$.

Despite considerable observations as shown in Table 1, the underlying mechanism regarding the formation of Al-Fe IMCs is still lacking albeit phase stability is known to be regulated by processing history involving $T$ - and $P$-profiles for a given chemistry ${ }^{45}$. Phase diagram, as the beginning of wisdom to guide any work in materials science and engineering ${ }^{46}$, is the most used tool to analyze equilibrium IMCs under a given temperature and composition (usually under external pressure $P=0 \mathrm{GPa}$ ). Additionally, non-equilibrium simulations in terms of the ScheilGulliver model ${ }^{47,48}$ can be used to analyze the forming IMCs in fast cooling processes by assuming that no diffusion takes place in the solid and that solute redistribution in the liquid is infinitely fast 49-51. The Scheil simulations have been used to, for example, design optimal composition for additively manufactured functionally graded metals ${ }^{49,50}$ and predict liquidus and solidus temperatures of steel ${ }^{51}$. In addition to phase diagram, non-equilibrium IMCs can be predicted by calculating thermodynamic driving forces for the phases of interest with respect to supercooled liquid and associated solid phases; see the predicted interface phases at the $\mathrm{Cu} /$ solder joints by Lee et al. ${ }^{52}$. Also based on thermodynamics, non-equilibrium IMCs can be tailored by partitionless solidification or by chemical partition solidification with limited atomic diffusions; for example, the non-equilibrium solidification predicted in the Al-Sm system by Zhou and Napolitano ${ }^{53}$. It should be remarked that thermodynamic knowledge in the literature is usually at the ambient pressure or external pressure $P=0 \mathrm{GPa}$, thus hindering the analysis of $P$-favored phases such as $\mathrm{Al}_{6} \mathrm{Fe}$ in the present work. In addition to thermodynamics, kinetics (diffusion) is another factor to regulate nucleation, growth, and coarsening of IMCs ${ }^{54,55}$. For example, $\mathrm{Al}_{5} \mathrm{Fe}_{2}$ and $\mathrm{Al}_{13} \mathrm{Fe}_{4}$ were 
formed due mainly to $\mathrm{Al}$ and/or Fe interdiffusion in some processes; see the examples \#13, \#17, $\# 18, \# 30, \# 31$, and \#32 in Table 1.

The present work aims to unveil the forming mechanism of equilibrium and non-equilibrium IMCs in dissimilar aluminum to steel joints based on thermodynamic knowledge in the Al-Fe system from (1) the present first-principles and phonon calculations based on density functional theory (DFT) and (2) the CALPHAD modeling by Sundman et al. ${ }^{9}$; and kinetic (diffusion) knowledge reported in the literature ${ }^{40,56,57}$. A special attention in the present DFT calculations is paid to the $P$-included Gibbs energy in addition to the variable of temperature. The challenge for the present DFT calculations is the unknown atomic configurations of (i) $\mathrm{Al}_{5} \mathrm{Fe}_{2}$ caused by the partially occupied Wyckoff sites $4 \mathrm{~b}$ and $8 \mathrm{f}$ of space group $\mathrm{Cmcm}^{58}$ and (ii) $\mathrm{Al}_{2} \mathrm{Fe}$ caused by the disordered $\mathrm{Al}$ and $\mathrm{Fe}$ in one of the Wyckoff sites $2 \mathrm{i}$ of space group $P \overline{1}^{59}$. To address this challenge, we adopt the following three approaches: (1) DFT-based USPEX (Universal Structure Predictor: Evolutionary Xtallography) predictions ${ }^{60}$, (2) DFT-based examinations of all possible configurations for a given supercell, and (3) datamining by examining all possible configurations in the literature with their formation energies predicted by machine learning. In addition to the conventional equilibrium phase diagram, the presently Scheil non-equilibrium simulations are also used to analyze the formation of Al-Fe IMCs. The present work indicates that the forming mechanism of IMCs in dissimilar Al-Fe joints (see examples in Table 1) can be explained well using phase diagram, Scheil simulations, thermodynamic driving forces, $P$ - and $T$-included Gibbs energies, and atomic diffusion coefficients in the Al-Fe system.

\section{Methodology}




\subsection{Atomic configurations of Al-Fe IMCs}

Most of the Al-Fe IMCs together with the constituent elements of FCC Al and BCC Fe are ordered structures. Their structures can be found in such as the Materials Project (MP) database ${ }^{61}$ and the Open Quantum Materials Database (OQMD) ${ }^{62}$; see the Supplementary Table S 1. However, $\mathrm{Al}_{5} \mathrm{Fe}_{2}$ is an IMC with vacancies (Va) in its Wyckoff sites for $\mathrm{Al}$ atoms ${ }^{58}$. The structure of $\mathrm{Al}_{5} \mathrm{Fe}_{2}$ can be depicted by the following sublattice model according to its Wyckoff sites 4c, 8g, 4b (occupation of 0.32 by $\mathrm{Al}$ ), and $8 \mathrm{f}$ (occupation of 0.24 by $\mathrm{Al}$ ) of space group $\mathrm{Cmcm}^{58}$, respectively,

$$
(\mathrm{Fe})_{4}^{c}(\mathrm{Al})_{8}^{g}(\mathrm{Al}, \mathrm{Va})_{4}^{b}(\mathrm{Al}, \mathrm{Va})_{8}^{f}
$$

Eq. 1

For another IMC of $\mathrm{Al}_{2} \mathrm{Fe}$, Chumak et al. ${ }^{59}$ indicated that it belongs to space group $P \overline{1}$ with one of its Wyckoff sites 2i mixed with Fe (occupation of 0.705) and Al (occupation of 0.295),

$$
(\mathrm{Fe})_{10}(\mathrm{Al})_{24}(\mathrm{Al}, \mathrm{Fe})_{4}^{i}
$$

Atomic configurations of $\mathrm{Al}_{5} \mathrm{Fe}_{2}$ were determined as follows in the present work. First, all the independent $\mathrm{Al}_{5} \mathrm{Fe}_{2}$ configurations were generated by the ATAT code ${ }^{63}$ using a 24-atom supercell, see Eq. 1. Second, we performed DFT calculations for the 14- to 16-atom configurations with one or two $\mathrm{Al}$ atoms in the Wyckoff sites $4 \mathrm{~b}$ and $8 \mathrm{f}$, respectively. For the composition of $\mathrm{Al}_{5} \mathrm{Fe}_{2}$, we also used the universal structure predictor - USPEX ${ }^{60,64}$ - to predict the lowest energy configuration in terms of a 14-atom supercell; where the computational engine of USPEX is the DFT-based calculations (see also Sec. 2.3). In addition, we also included the low energy configurations of $\mathrm{Al}_{5} \mathrm{Fe}_{2}$ suggested by Vinokur et al. ${ }^{65}$. 
Atomic configurations of $\mathrm{Al}_{2} \mathrm{Fe}$ were also examined by the ATAT code ${ }^{63}$ based on the mixing of $\mathrm{Al}$ and $\mathrm{Fe}$ in Wyckoff site $2 \mathrm{i}$ (see Eq. 2) by using the 38- and 57-atom supercells of $\mathrm{Al}_{2} \mathrm{Fe}$. In addition, the suggested $\mathrm{MoSi}_{2}$-type configuration by Tobita et al. ${ }^{66}$ was included in the present work. Aiming to search for the possible configurations of $\mathrm{Al}_{2} \mathrm{Fe}$, we also adopted a datamining approach by considering all the $\mathrm{AB}_{2}$-type configurations ( 1.3 million) in the Materials Project (MP) database ${ }^{61}$, the Open Quantum Materials Database (OQMD) ${ }^{62}$, the Crystallography Open

Database (COD) ${ }^{67,68}$, and the Joint Automated Repository for Various Integrated Simulations (JARVIS) database ${ }^{69}$. The enthalpies of formation $\left(\Delta H_{0}\right)$ of these $\mathrm{AB}_{2}$-type configurations were predicted by machine learning (ML) in terms of the tool of SIPFENN (structure-informed prediction of formation energy using neural networks) ${ }^{70}$. Here, SIPFENN requires only atomic configurations and atomic species, which allows efficient integration into datamining study within minutes. On a random 5\% subset in the OQMD structures, SIPFENN could achieve a mean absolute error of $28 \mathrm{meV} /$ atom $\left(2.7 \mathrm{~kJ} / \mathrm{mol}\right.$-atom) to predict $\Delta H_{0}{ }^{70}$. For the SIPFENN suggested $\mathrm{A}_{2} \mathrm{~B}$-type configurations with lower $\Delta H_{0}$ values (more than 500 configurations were selected herein), we performed DFT-based verifications. Notably, the present datamining approach found that the lowest energy configuration of $\mathrm{Al}_{2} \mathrm{Fe}$ is also the $\mathrm{MoSi}_{2}$-type.

\subsection{First-principles thermodynamics}

Thermodynamic properties at finite temperatures can be predicted by DFT-based quasiharmonic approach, i.e., Helmholtz energy $F$ for a given phase as a function of volume $V$ and temperature $T$ is determined by ${ }^{71,72}$,

$$
F(V, T)=E(V)+E_{v i b}(V, T)+E_{e l}(V, T)-T\left[S_{v i b}(V, T)+S_{e l}(V, T)+S_{c o n f}\right] \quad \text { Eq. } 3
$$


Correspondingly, the Gibbs energy can be evaluated by $G(P, T)=\left.F(V, T)\right|_{P=f i x}+P V$ at the given pressure of interest. Here, $E_{v i b}(V, T)$ and $S_{v i b}(V, T)$ are vibrational contributions (internal energy and entropy, respectively) determined by phonon densities of states (DOS's, about 6 volumes were calculated for each phase) ${ }^{71,73} . E_{e l}(V, T)$ and $S_{e l}(V, T)$ are thermal electronic contributions (internal energy and entropy, respectively) determined by electronic DOS's ${ }^{71,73} . S_{\text {conf }}$ is ideal configurational entropy for the IMCs with partially occupied Wyckoff sites, i.e., $\mathrm{Al}_{5} \mathrm{Fe}_{2}$ (described by Eq. 1) and $\mathrm{Al}_{2} \mathrm{Fe}$ (Eq. 2),

$$
\begin{array}{cc}
S_{\text {conf }}^{\mathrm{Al}_{5} \mathrm{Fe}_{2}}=-\frac{4 R\left(y_{\mathrm{Al}}^{b} \log \left(y_{\mathrm{Al}}^{b}\right)+y_{\mathrm{Va}}^{b} \log \left(y_{\mathrm{Va}}^{b}\right)\right)}{24}-\frac{8 R\left(y_{\mathrm{Al}}^{f} \log \left(y_{\mathrm{Al}}^{f}\right)+y_{\mathrm{Va}}^{f} \log \left(y_{\mathrm{Va}}^{f}\right)\right)}{24} & \text { Eq. } 4 \\
S_{\text {conf }}^{\mathrm{Al}_{2} \mathrm{Fe}}=-\frac{4 R\left(y_{\mathrm{Al}}^{i} \log \left(y_{\mathrm{Al}}^{i}\right)+y_{\mathrm{Fe}}^{i} \log \left(y_{\mathrm{Fe}}^{i}\right)\right)}{38} & \text { Eq. } 5
\end{array}
$$

where $R$ is gas constant and $y$ the site fraction with the superscript being Wyckoff site (sublattice). Based on experimental measurements for $\mathrm{Al}_{5} \mathrm{Fe}_{2}{ }^{58}, y_{\mathrm{Al}}^{b}=0.32\left(y_{\mathrm{Al}}^{f}=0.24\right)$ and $y_{\mathrm{Va}}^{b}=0.68$ $\left(y_{\mathrm{Va}}^{f}=0.76\right)$ for $\mathrm{Al}$ and $\mathrm{Va}$, respectively. Correspondingly, $y_{\mathrm{Al}}^{i}=0.295$ and $y_{\mathrm{Fe}}^{i}=0.705$ based on experiments for $\mathrm{Al}_{2} \mathrm{Fe}^{59}$.

$E(V)$ in Eq. 3 is the static energy at $0 \mathrm{~K}$ without the zero-point vibrational energy, which was determined by fitting the DFT calculated energy-volume $(E-V)$ data points using a four-parameter Birch-Murnaghan equation of state (EOS) ${ }^{71}$,

$$
E(V)=k_{1}+k_{2} V^{-2 / 3}+k_{3} V^{-4 / 3}+k_{4} V^{-2}
$$

where $k_{1}, k_{2}, k_{3}$, and $k_{4}$ are fitting parameters. Equilibrium properties for each phase from this EOS include the equilibrium energy $E_{0}$, volume $V_{0}$, bulk modulus $B_{0}$, and the pressure derivative of 
bulk modulus $B^{\prime}$. Usually, eight reliable data points were used for each EOS fitting in the present work.

\subsection{Details of first-principles calculations}

All DFT-based first-principles calculations in the present work were performed by the Vienna $A b$ initio Simulation Package (VASP) ${ }^{74}$ with the ion-electron interaction described by the projector augmented wave method ${ }^{75}$ and the exchange-correlation functional described by the generalized gradient approximation (GGA) developed by Perdew, Burke, and Ernzerhof (PBE) ${ }^{76}$. The same as those in the Materials Project ${ }^{61}$, three electrons $\left(3 s^{2} 3 p^{1}\right)$ were treated as valence electrons for $\mathrm{Al}$ and fourteen $\left(3 \mathrm{p}^{6} 3 \mathrm{~d}^{7} 4 \mathrm{~s}^{1}\right)$ for Fe. In the VASP calculations, a plane wave cutoff energy of 293.2 $\mathrm{eV}$ was employed for structural relaxations and phonon calculations in terms of the MethfesselPaxton method ${ }^{77}$. Final calculations of total energies and electronic DOS's were performed by the tetrahedron method with a Blöchl correction ${ }^{78}$ using a wave cutoff energy of $520 \mathrm{eV}$. The employed $k$-points meshes for each structure are listed in the Supplementary Table S 1. The selfconsistency of total energy was converged to at least $10^{-6} \mathrm{eV} / \mathrm{atom}$. Due to the magnetic nature of $\mathrm{Fe}$, all Fe-containing materials were performed by the spin polarization calculations.

Phonon calculations were performed for each structure using the supercell approach ${ }^{79}$ in terms of the YPHON code ${ }^{80}$. Here, the VASP code was again the computational engine in calculating force constants using the finite differences method. The employed supercell for each structure and the corresponding $k$-points meshes are given in the Supplementary Table S 1 . In addition, the single crystal elastic constants $C_{\mathrm{ij}}$ 's in the Al-Fe system were determined by applying the stress-strain method with the non-zero strains being \pm 0.01 ; see details in ${ }^{81,82}$. The aggregate properties for 
polycrystal were determined by using the Hill $(\mathrm{H})$ approach ${ }^{83,84}$ based on the $C_{\mathrm{ij}}$ values, including bulk modulus $\left(B_{\mathrm{H}}\right)$, shear modulus $\left(G_{\mathrm{H}}\right), B_{\mathrm{H}} / G_{\mathrm{H}}$ ratio, Poisson's ratio $\left(v_{\mathrm{H}}\right)$, and the anisotropy index $A^{\mathrm{U}}{ }^{85}$. Note that the suggested DFT settings by USPEX ${ }^{60,64}$ were used in the present work, aiming at searching for the low energy configurations of $\mathrm{Al}_{5} \mathrm{Fe}_{2}$ by USPEX.

\subsection{Formation of non-equilibrium IMCs through thermodynamic analysis}

The decrease in Gibbs energy, $-\Delta G_{m}^{\alpha}$, for the precipitation of a new phase $\alpha$ (e.g., IMC) from a supersaturated solution (e.g., the supercooled liquid), is the thermodynamic driving force of formation, $D$, of the new $\alpha$ phase, i.e., $D=-\Delta G_{m}^{\alpha}{ }^{86}$. The IMC with the highest thermodynamic driving force of formation can be selected as the IMC that would form first, making the driving force $D$ a reasonable criterion to predict the first-forming IMC ${ }^{52}$. Similarly to the analysis of interface phases formed at the $\mathrm{Cu} /$ solder joints by Lee et al. ${ }^{52}$, for example, Figure $\mathbf{1}$ shows that at $1000 \mathrm{~K}$ of the $\mathrm{Al}-\mathrm{Fe}$ system, the supercooled liquid has a composition $x_{\mathrm{Fe}}=0.163$ (mole fraction of $\mathrm{Fe}$ in the metastable liquidus), which is in equilibrium with the supersaturated $\mathrm{BCC}$ phase (i.e., the metastable solidus) with $x_{\mathrm{Fe}}=0.281$. At this composition $\left(x_{\mathrm{Fe}}=0.281\right)$, we can calculate thermodynamic driving forces of the $\mathrm{IMCs}$ (such as $\mathrm{Al}_{13} \mathrm{Fe}_{4}, \mathrm{Al}_{5} \mathrm{Fe}_{2}, \mathrm{Al}_{2} \mathrm{Fe}$, and $\mathrm{Al}_{8} \mathrm{Fe}_{5}$ ) formed from the supersaturated $\mathrm{BCC}$ phase — the higher the driving force, the larger the possibility to form this IMC. In the present work, thermodynamic driving forces of the formation of IMCs from the supersaturated $\mathrm{BCC}$ phase were calculated as a function of temperature using the modeled AlFe system by Sundman et al. ${ }^{9}$ and the Thermo-Calc software ${ }^{55}$.

In addition to thermodynamic driving force, we can also use the non-equilibrium phase diagram, 
predicted by the Scheil-Gulliver simulations ${ }^{47,48}$ (see its definition in the Introduction section), to predict the formation of IMCs in fast cooling processes, such as the AM process ${ }^{49,50}$. Here, we used the PyCalphad software ${ }^{50,87}$ to calculate this non-equilibrium phase diagram with the thermodynamic description modelled by Sundman et al. ${ }^{9}$.

\section{Results and Discussion}

\subsection{DFT-based phase stability of IMCs with respect to temperature and pressure}

Figure 3 shows the predicted values of enthalpy of formation $\left(\Delta \mathrm{H}_{0}\right)$ for the Al-Fe IMCs based on the present DFT calculations at $T=0 \mathrm{~K}$ and $P=0 \mathrm{GPa}$. Detailed atomic configuration and $\Delta \mathrm{H}_{0}$ value of each IMC are given in the Supplementary Table S 1; especially the predicted 14-atom configuration of $\mathrm{Al}_{5} \mathrm{Fe}_{2}$ by USPEX ${ }^{60,64}$ is listed in the Supplementary Table S 2. In addition, Figure 3 shows also the convex hull by DFT calculations to display the stable IMCs, the experimental $\Delta \mathrm{H}_{0}$ values collected by Sundman et al. ${ }^{9}$ to measure the quality of the present DFT calculations, and the unstable configurations judged by imaginary phonon modes (not shown). It is seen (in Figure 3) that (i) the DFT-predicted $\Delta \mathrm{H}_{0}$ values agree well with the experimental data which are scattered; (ii) $\mathrm{Al}_{6} \mathrm{Fe}$ is close to but above the convex hull, indicating that it is metastable at $T=0 \mathrm{~K}$ and $P=0 \mathrm{GPa}$, and more attentions need to be paid for its phase stability at high temperatures and high pressures; (iii) $\mathrm{Al}_{9} \mathrm{Fe}_{2}$ is an unstable structure and hence ignored in the present work; (iv) $\mathrm{Al}_{5} \mathrm{Fe}_{2}$ is a metastable phase at $T=0 \mathrm{~K}$ and $P=0 \mathrm{GPa}$, albeit various configurations have been examined in the present work (see the green open squares as well as the details in Table S 1); (v) the $\mathrm{MoSi}_{2}$-type $\mathrm{Al}_{2} \mathrm{Fe}$ possesses the lowest energy and on the convex hull at $T=0 \mathrm{~K}$ and $P=0 \mathrm{GPa}$; and (vi) the IMCs of $\mathrm{Al}_{13} \mathrm{Fe}_{4}, \mathrm{AlFe}$, and $\mathrm{AlFe}_{3}$ are stable phases based on the convex hull. Figure 3 implies that, at the conditions of $T=0 \mathrm{~K}$ and $P=0 \mathrm{GPa}$, the presently 
predicted $\Delta \mathrm{H}_{0}$ values for $\mathrm{Al}_{5} \mathrm{Fe}_{2}$ and non- $\mathrm{MoSi}_{2}$-type $\mathrm{Al}_{2} \mathrm{Fe}$ (i.e., the triclinic $\mathrm{Al}_{2} \mathrm{Fe}^{59}$ ) are close to but above the convex hull, indicating that (a) the supercells used herein may be too small to search for the stable atomic configurations, and (b) more effects on phase stability such as temperature and pressure need to be considered. To this end as well as the suggestions by Figure 3, phase stabilities of $\mathrm{Al}_{6} \mathrm{Fe}, \mathrm{Al}_{5} \mathrm{Fe}_{2}$, and $\mathrm{Al}_{2} \mathrm{Fe}$ are further examined at finite temperatures and finite pressures (see Figure 4).

Figure 4 shows the changes of Gibbs energy, $\Delta G_{\text {reac }}$, as a function of temperature and pressure ( $P$ $=0$ and $6 \mathrm{GPa}$ as two examples) for the following three reactions,

$$
\begin{array}{lc}
\mathrm{R} 1: \mathrm{Al}_{13} \mathrm{Fe}_{4}+11 \mathrm{Al}=4 \mathrm{Al}_{6} \mathrm{Fe} & \text { Eq. } 7 \\
\text { R2: } \mathrm{Al}_{13} \mathrm{Fe}_{4}+2 \mathrm{AlFe}=3 \mathrm{Al}_{5} \mathrm{Fe}_{2} & \text { Eq. } 8 \\
\text { R3: } \mathrm{Al}_{13} \mathrm{Fe}_{4}+5 \mathrm{AlFe}=9 \mathrm{Al}_{2} \mathrm{Fe} & \text { Eq. } 9
\end{array}
$$

Here we choose the stable phases of $\mathrm{Al}, \mathrm{Al}_{13} \mathrm{Fe}_{4}$, and $\mathrm{AlFe}$ (the $\mathrm{B} 2$ structure) as the reference states to examine phase stability of $\mathrm{Al}_{6} \mathrm{Fe}, \mathrm{Al}_{5} \mathrm{Fe}_{2}$ (using the configuration predicted by USPEX), and $\mathrm{Al}_{2} \mathrm{Fe}$ (using the $\mathrm{MoSi}_{2}$-type configuration predicted by SIPFENN). It shows that $\mathrm{Al}_{6} \mathrm{Fe}$ is a $T$ unfavored (see R1 in Figure 4a), but it is a $P$-favored phase (see R1 in Figure 4b). Phase stability of $\mathrm{Al}_{6} \mathrm{Fe}$ (as well as other IMCs) at finite temperatures and under a given pressure can be understood by vibrational entropy, $S_{v i b}$, in terms of the phonon density of states (DOS), $g(\omega)^{88}$,

$$
S_{v i b} \propto \int g(\omega) \ln (\omega) d \omega
$$

Eq. 10

where $\omega$ is phonon frequency. Eq. 10 indicates that the higher the phonon DOS in the low $\omega$ region, the higher the $S_{v i b}$ contribution to Gibbs energy will be (see Eq. 3) ${ }^{54,88,89}$. Figure 5 shows the phonon DOS's of FCC Al and the selected Al-Fe IMCs at $P=0$ GPa. In general, it shows that 
the $g(\omega)$ of $\mathrm{Al}$ has the highest density than Al-Fe IMCs at the low frequency region (e.g., $\omega<6$ $\mathrm{THz}$ ), since $\mathrm{FCC} \mathrm{Al}$ is the softest material with the largest equilibrium volume $V_{0}$ and the smallest bulk modulus $B_{0}$ in the Al-Fe system; see the Supplementary Table S 1. Relevant to the reaction R1 (Eq. 7) and at the low frequency region $(\omega<6 \mathrm{THz})$, Figure 5 shows that the $g(\omega)$ of $\mathrm{Al}$ is much higher than that of $\mathrm{Al}_{6} \mathrm{Fe}$ with $3.5<\omega<6 \mathrm{THz}$, but the $g(\omega)$ of $\mathrm{Al}_{6} \mathrm{Fe}$ has higher values in a small region with $\omega<2 \mathrm{THz}$. In addition, the phonon DOS's of $\mathrm{Al}$ and $\mathrm{Al}_{13} \mathrm{Fe}_{4}$ do not have significant differences at the low frequency region. These features imply that the $S_{v i b}$ contributions to both $\mathrm{Al}$ and $\mathrm{Al}_{13} \mathrm{Fe}_{4}$ should be slightly higher than that of $\mathrm{Al}_{6} \mathrm{Fe}$, resulting a slight increase of $\Delta G_{\text {reac }}$ for reaction R1 with increasing temperature (at $P=0 \mathrm{GPa}$ ). At higher pressures such as $P$ $=6 \mathrm{GPa}, \Delta G_{\text {reac }}$ for reaction R1 keeps roughly constant since the $S_{v i b}$ contributions to both $\mathrm{Al}$ and $\mathrm{Al}_{13} \mathrm{Fe}_{4}$ are nearly identical to that of $\mathrm{Al}_{6} \mathrm{Fe}$. Figure $4 \mathrm{~b}$ shows that with increasing pressure (even less than $1 \mathrm{GPa}$ ) instead of increasing temperature, $\mathrm{Al}_{6} \mathrm{Fe}$ becomes stable with respect to $\mathrm{Al}$ and $\mathrm{Al}_{13} \mathrm{Fe}_{4}$ ( $c f$. ., the reaction R1). Based on experimental observations such as the examples \#1 to \#5 in Table 1, $\mathrm{Al}_{6} \mathrm{Fe}$ was formed in the processes associated with pressures (such as die casting and equal channel angular extrusion) and in high Al-containing samples (e.g., $x_{\mathrm{Al}}>0.9$ ).

The reaction R2 (see Eq. 8) in Figure 4a and b shows that $\mathrm{Al}_{5} \mathrm{Fe}_{2}$ is a $T$-unfavored but $P$-favored phase by ignoring the contribution of configurational entropy $S_{\text {conf; }}$; see Eq. 3 and Eq. 4 . The $T$ unfavored $\mathrm{Al}_{5} \mathrm{Fe}_{2}$ is due mainly to the lower phonon DOS of $\mathrm{Al}_{5} \mathrm{Fe}_{2}$ compared to that of $\mathrm{AlFe}$ with frequency $\omega$ around $4 \mathrm{THz}$ (Figure 5). With $S_{\text {conf }}$ contribution to $\Delta G_{\text {reac }}$ for reaction $\mathrm{R} 2, \mathrm{Al}_{5} \mathrm{Fe}_{2}$ becomes both the $T$ - and $P$-favored phase (see the blue dash lines of R2). These results indicate that the factors, including atomic configuration, temperature, pressure, and $S_{\text {conf }}$, make $\mathrm{Al}_{5} \mathrm{Fe}_{2}$ more stable. 
Figure 4 shows that the $\mathrm{MoSi}_{2}$-type $\mathrm{Al}_{2} \mathrm{Fe}$ is $T$-unfavored, but it is a strong $P$-favored phase. In addition, the $S_{\text {conf }}$ has less contribution to $\Delta G_{\text {reac }}$ in comparison with that for $\mathrm{Al}_{5} \mathrm{Fe}_{2}$, due to the less partially occupied Wyckoff site of $\mathrm{Al}_{2} \mathrm{Fe}$; see Eq. 4 and Eq. 5. The $T$-unfavored behavior is caused by the lower phonon DOS of $\mathrm{Al}_{2} \mathrm{Fe}$ than those of $\mathrm{AlFe}$ and $\mathrm{Al}_{13} \mathrm{Fe}_{4}$; see the $\omega$ range from 2 to $7 \mathrm{THz}$ (Figure 5). With increasing pressure, Figure 4 shows that the $\Delta G_{\text {reac }}$ value of reaction R3 decreases greatly; for example, dropping more than $2 \mathrm{~kJ} / \mathrm{mol}$-atom at $T=0 \mathrm{~K}$ as well as at other temperatures. Experimentally, the $\mathrm{MoSi}_{2}$-type $\mathrm{Al}_{2} \mathrm{Fe}$ was synthesized through the laser-heated diamond-anvil cell at $10 \mathrm{GPa}$ and $1873 \mathrm{~K}^{90}$, and it was suggested that it is a high pressure phase existed with $P>5 \mathrm{GPa}^{66}$; agreeing with the present conclusion that $\mathrm{Al}_{2} \mathrm{Fe}$ is a $T$-unfavored but a strong $P$-favored phase, albeit it is stable at $T=0 \mathrm{~K}$ and $P=0 \mathrm{GPa}$ (Figure 3).

Figure 6 shows a schematic $P-T$ phase diagram (demonstrated with $P=0$ and $6 \mathrm{GPa}$ ) for the AlFe system based on the present DFT calculations using Eq. 3. It shows that $\mathrm{Al}_{13} \mathrm{Fe}_{4}, \mathrm{AlFe}$, and $\mathrm{AlFe}_{3}$ are already the stable IMCs marked by the shaded regions. However, at low pressures and low temperatures (e.g., $P=0 \mathrm{GPa}$ and $T<165 \mathrm{~K}$ ), the $\mathrm{L}_{2}$-type $\mathrm{AlFe}_{3}$ is more stable than the $\mathrm{D}_{3}$ type $\mathrm{AlFe}_{3}$. In all temperature range in Figure 6, $\mathrm{Al}_{6} \mathrm{Fe}$ is not stable when $P=0 \mathrm{GPa}$ but stable at higher pressures. $\mathrm{Al}_{5} \mathrm{Fe}_{2}$ (configuration predicted by USPEX) is stable at high temperatures (e.g., $T>345 \mathrm{~K}$ with $P=0 \mathrm{GPa}$ ), while the pressure decreases its stability slightly. The MoSi 2 -type $\mathrm{Al}_{2} \mathrm{Fe}$ is a $T$-unfavored but a strong $P$-favored phase.

Table 2 summarizes phase stability of Al-Fe IMCs as a function of pressure and temperature as shown in Figure 1, Figure 3, and Figure 6; together with their ductility/brittleness judged by 
Pugh's criterion ${ }^{11,12}$ as shown in Figure 2, which were determined by the presently predicted elastic constants in Table S 3.

\subsection{Phase stability of Al-Fe IMCs by thermodynamic and kinetic analyses}

Figure 7 shows the predicted thermodynamic driving forces of the Al-Fe IMCs in the temperature range, $920 \mathrm{~K}<T<1320 \mathrm{~K}$, together with the associated mole fraction of $\mathrm{Fe}\left(x_{\mathrm{Fe}}\right)$ along the metastable solidus line in Figure 1. Note that the eutectic reaction temperature is $927 \mathrm{~K}$ and the used thermodynamic description was modelled by Sundman et al. ${ }^{9}$. It is seen that both $\mathrm{Al}_{13} \mathrm{Fe}_{4}$ and $\mathrm{Al}_{5} \mathrm{Fe}_{2}$ have the higher thermodynamic driving forces of formation at lower temperatures $(<$ $1280 \mathrm{~K}$ ) than those of $\mathrm{Al}_{2} \mathrm{Fe}$ and $\mathrm{Al}_{8} \mathrm{Fe}_{5}$. By examining atomic diffusivity in Al-Fe IMCs, the interdiffusion coefficients in $\mathrm{Al}_{5} \mathrm{Fe}_{2}$ are at least two orders of magnitude faster than those in the other IMCs $\left(\mathrm{AlFe}, \mathrm{Al}_{2} \mathrm{Fe}\right.$, and $\left.\mathrm{Al}_{13} \mathrm{Fe}_{4}\right)$ at $T=823-913 \mathrm{~K}$; ; and they are comparable with the diffusion coefficients of dilute Fe in FCC Al; see Figure 8 based on diffusion coefficients reported in the literature ${ }^{40,56,57}$. In addition, $\mathrm{Al}$ atoms have higher diffusivity in $\mathrm{Al}_{5} \mathrm{Fe}_{2}$ than $\mathrm{Fe}$ atoms ${ }^{36}$. The fastest atomic diffusivity, especially $\mathrm{Al}$ atoms, in $\mathrm{Al}_{5} \mathrm{Fe}_{2}$ is due mainly to the rich $\mathrm{Al}$ vacancies in $\mathrm{Al}_{5} \mathrm{Fe}_{2}{ }^{58}$; see Eq. 1 . However, considerable vacancies have not been reported in the other AlFe IMCs. By considering both the high thermodynamic driving force of formation (Figure 7) and the fastest interdiffusion coefficients (Figure 8), the brittle $\mathrm{Al}_{5} \mathrm{Fe}_{2}$ is the IMC with the largest possibility to be formed; see the Al-rich examples in Table 1, except for the samples with extremely high $\mathrm{Al}$ contents, or formed below the eutectic reaction temperature of $927 \mathrm{~K}$, or processed by AM (examples \#1 to \#5, and \#7 to \#11).

As two examples, Figure 9 shows the calculated mole fractions of solid phases by Scheil 
simulations using the thermodynamic description modelled by Sundman et al. ${ }^{9}$. With decreasing tempeature at the fixed composition of $x_{\mathrm{Fe}}=0.3$, the solid phase of $\mathrm{Al}_{5} \mathrm{Fe}_{2}$ forms first and reaches a maximum mole fracition about 0.5 at $T=1427.5 \mathrm{~K}$, and then the second solid phase of $\mathrm{Al}_{8} \mathrm{Fe}_{5}$ forms at almost the fixed temperature of $1427.5 \mathrm{~K}$. Due to the exteremely small temperture range $(\ll<1 \mathrm{~K})$ for phase transition, $\mathrm{Al}_{8} \mathrm{Fe}_{5}$ was not observed in all the processes in Table 1 . For the case of $x_{\mathrm{Fe}}=0.6$, the first formed solid phase is BCC (or B2 phase) with decreasing temperature and reaches a maximum mole fraction of 0.95 , and then $\mathrm{Al}_{8} \mathrm{Fe}_{5}$ forms in a small temperature range of $1505 \sim 1493 \mathrm{~K}$. Similar to the case of $x_{\mathrm{Fe}}=0.3$, the predicted $\mathrm{Al}_{8} \mathrm{Fe}_{5}$ was also not observed in the processes in Table 1 due probably to the small temperature range of phase formation. Figure 10 shows the complete non-equilibrium phase diagram by Scheil simulations using the modelled AlFe system by Sundman et al. ${ }^{9}$. This non-equilibrium phase diagram shows the temperatures of the forming phases, while the lever rule cannot be used to determine phase fractions. Both the equilibrium phase diagram (Figure 1) and the Schiel non-equilibrium phase diagram (Figure 10) can be used to determine the forming phases in the slow/equilibrium and the fast cooling processes, respectively.

As an example, Figure 11 show the forming phases as a function of temperature with $x_{\mathrm{Fe}}=0.4$. The forming phases are $\mathrm{BCC}$ (minor) and $\mathrm{Al}_{8} \mathrm{Fe}_{5}$ (major) based on Schiel simulations (see also Figure 10), while the forming phases are $\mathrm{Al}_{8} \mathrm{Fe}_{5}$ (when $T>1360 \mathrm{~K}$ ), $\mathrm{BCC}$, and $\mathrm{Al}_{2} \mathrm{Fe}$ based on equilibrium calculaitions (see also Figure 1). Therefore, the forming phases coule be $\mathrm{BCC}, \mathrm{Al}_{2} \mathrm{Fe}$, and/or $\mathrm{Al}_{8} \mathrm{Fe}_{5}$ depended on the processes. For instance, Stein et al. ${ }^{91}$ observed the eutectoid reaction of $\mathrm{Al}_{8} \mathrm{Fe}_{5} \leftrightarrow \mathrm{Al}_{2} \mathrm{Fe}+\mathrm{BCC}$ (B2) at $1368 \mathrm{~K}$ according to the differential thermal analyses for the $\mathrm{Al}-40$ at. $\% \mathrm{Fe}$ alloy $\left(x_{\mathrm{Fe}}=0.4\right)$ at the heating rates of 5 and $10 \mathrm{~K} / \mathrm{min}$. 
It should be mentioned that the forming phases depend mainly on compositions (especially the local compositions) in addition to temperature, pressure, and atomic diffusivity for the system of interest. Table 1 shows that AM is a superior process than the other processes to achieve desired phases such as $\mathrm{AlFe}$ and $\mathrm{AlFe}_{3}$ through varying the compositions. Aiming to predict the forming IMCs under a given composition and a given processing history, the combined thermodynamic and kinetic simulations are needed. For example, Lindwall et al. ${ }^{92}$ simulated the time-temperaturetransformation (TTT) diagram and the forming IMCs in the additively manufactured Ni-based Inconel 625. However, these simulations are beyond the scope of the present work.

\section{Summary}

The present work investigated the forming mechanism of equilibrium and non-equilibrium intermetallic compounds (IMCs) in aluminum/steel (Al-Fe) joints by means of Gibbs energy as a function of temperature $(T)$ and pressure $(P)$ from (i) the first-principles phonon calculations, (ii) the equilibrium Al-Fe phase diagram in the literature and the presently predicted non-equilibrium phase diagram by Scheil simulations, (iii) atomic diffusivity in Al-Fe, and (iv) experimentally observed IMCs in various processes. Specially, the unknown atomic configurations of $\mathrm{Al}_{2} \mathrm{Fe}$ and $\mathrm{Al}_{5} \mathrm{Fe}_{2}$ were examined in the present work by machine learning based datamining together with first-principles verifications and structure predictor (using USPEX).

We conclude that the formation of IMCs can be explained well by using phase diagrams, thermodynamic driving forces, $P$ - and $T$-included Gibbs energy, and atomic diffusion coefficients. 
Specifically, the metastable while ductile $\mathrm{Al}_{6} \mathrm{Fe}$ is a $P$-favored IMC, which was observed in $\mathrm{Al}$ dominant samples and the processes involving pressures such as direct-chill casting, die casting, equal channel angular extrusion. Here the ductility and brittleness of IMCs were judged by Pugh's criterion ${ }^{11,12}$ using the presently predicted elastic constants. The $\mathrm{MoSi}_{2}$-type $\mathrm{Al}_{2} \mathrm{Fe}$ is a brittle and a strong $P$-favored IMC observed at high pressures. The stable but brittle $\eta-\mathrm{Al}_{5} \mathrm{Fe}_{2}$ is the most observed IMC usually adjacent to steel $(\mathrm{Fe})$ in almost all the processes (see Table 1), such as the fusion or solid-state welding, immersion test, diffusion couple, and additive manufacturing (AM), since $\mathrm{Al}_{5} \mathrm{Fe}_{2}$ is a $T$-favored phase with a high thermodynamic driving force of formation and the fastest atomic diffusivity among all $\mathrm{Al}-\mathrm{Fe}$ IMCs. The slightly brittle $\theta-\mathrm{Al}_{13} \mathrm{Fe}_{4}$ is the second most observed IMC usually adjacent to $\mathrm{Al}$ shown in most of the processes, which possesses the highest thermodynamic driving force of formation in Al-rich side. Notably the ductile $\mathrm{AlFe}_{3}$, the less ductile AlFe, and almost all the other IMCs were observed in the AM processes, making AM an exceptional way to tailor composition and in turn achieve the desired IMCs in dissimilar materials. All the IMCs (without the $P$-favored phases) formed in the Al-Fe joints can be identified using the equilibrium and the Scheil non-equilibrium phase diagrams, together with kinetic considerations. 


\section{Declaration of Competing Interest}

The authors declare that they have no known competing financial interests or personal relationships that could have appeared to influence the work reported in this paper.

\section{Acknowledgments}

The authors acknowledge the financial support partially by the U.S. Department of Energy (DOE) via Award No. DE-EE0008456; and partially by the National Science Foundation (NSF) with Grant No. CMMI-1825538. First-principles calculations were performed partially on the Roar supercomputer at the Pennsylvania State University's Institute for Computational and Data Sciences (ICDS), partially on the resources of the National Energy Research Scientific Computing Center (NERSC) supported by the U.S. DOE Office of Science User Facility operated under Contract No. DE-AC02-05CH11231, and partially on the resources of the Extreme Science and Engineering Discovery Environment (XSEDE) supported by NSF with Grant No. ACI-1548562. 


\section{References:}

1. Wang, P., Chen, X., Pan, Q., Madigan, B. \& Long, J. Laser welding dissimilar materials of aluminum to steel: an overview. Int. J. Adv. Manuf. Technol. 87, 3081-3090 (2016).

2. Sakundarini, N., Taha, Z., Abdul-Rashid, S. H. \& Ghazila, R. A. R. Optimal multimaterial selection for lightweight design of automotive body assembly incorporating recyclability. Mater. Des. 50, 846-857 (2013).

3. Wargnier, H., Kromm, F. X., Danis, M. \& Brechet, Y. Proposal for a multi-material design procedure. Mater. Des. 56, 44-49 (2014).

4. Bahraminasab, M. et al. Multi-objective design optimization of functionally graded material for the femoral component of a total knee replacement. Mater. Des. 53, 159-173 (2014).

5. Aizawa, T., Okagawa, K. \& Kashani, M. Application of magnetic pulse welding technique for flexible printed circuit boards (FPCB) lap joints. J. Mater. Process. Technol. 213, 1095-1102 (2013).

6. Springer, H., Kostka, A., dos Santos, J. F. \& Raabe, D. Influence of intermetallic phases and Kirkendall-porosity on the mechanical properties of joints between steel and aluminium alloys. Mater. Sci. Eng. A 528, 4630-4642 (2011).

7. Safeen, M. W. \& Russo Spena, P. Main Issues in Quality of Friction Stir Welding Joints of Aluminum Alloy and Steel Sheets. Metals (Basel). 9, 610 (2019).

8. Hussein, S. A., Tahir, A. S. M. \& Hadzley, A. B. Characteristics of aluminum-to-steel joint made by friction stir welding: A review. Mater. Today Commun. 5, 32-49 (2015).

9. Sundman, B., Ohnuma, I., Dupin, N., Kattner, U. R. \& Fries, S. G. An assessment of the entire Al-Fe system including D03 ordering. Acta Mater. 57, 2896-2908 (2009). 
10. Aliravci, C. A. \& Pekgüleryüz, M. Ö. Calculation of phase diagrams for the metastable Al-Fe phases forming in direct-chill (DC)-cast aluminum alloy ingots. Calphad 22, 147155 (1998).

11. Pugh, S. F. XCII. Relations between the elastic moduli and the plastic properties of polycrystalline pure metals. Philos. Mag. 45, 823-843 (1954).

12. Liu, Z. Q. et al. Electrically reversible cracks in an intermetallic film controlled by an electric field. Nat. Commun. 9, 41 (2018).

13. Zhu, X., Blake, P. \& Ji, S. The formation mechanism of Al6(Fe, Mn) in die-cast Al-Mg alloys. CrystEngComm 20, 3839-3848 (2018).

14. Yu, F., Liu, F., Zhao, D. \& Toth, L. S. Microstructure and mechanical properties of Al3Fe alloy processed by equal channel angular extrusion. in IOP Conference Series: Materials Science and Engineering vol. 63012079 (Institute of Physics Publishing, 2014).

15. He, H., Lin, S., Yang, C., Fan, C. \& Chen, Z. Combination Effects of Nocolok Flux with Ni Powder on Properties and Microstructures of Aluminum-Stainless Steel TIG WeldingBrazing Joint. J. Mater. Eng. Perform. 22, 3315-3323 (2013).

16. Qi, X., Takata, N., Suzuki, A., Kobashi, M. \& Kato, M. Laser powder bed fusion of a near-eutectic Al-Fe binary alloy: Processing and microstructure. Addit. Manuf. 35, 101308 (2020).

17. Shishkovsky, I., Missemer, F., Kakovkina, N. \& Smurov, I. Intermetallics Synthesis in the Fe-Al System via Layer by Layer 3D Laser Cladding. Crystals 3, 517-529 (2013).

18. Pęska, M., Karczewski, K., Rzeszotarska, M. \& Polański, M. Direct Synthesis of Fe-Al Alloys from Elemental Powders Using Laser Engineered Net Shaping. Materials (Basel). 13, $531(2020)$. 
19. Lotfian, S., Rolink, G., Weisheit, A. \& Palm, M. Chemically graded Fe-Al/steel samples fabricated by laser metal deposition. in MRS Advances vol. 2 1393-1398 (Materials Research Society, 2017).

20. Shen, C., Pan, Z., Cuiuri, D., Roberts, J. \& Li, H. Fabrication of Fe-FeAl Functionally Graded Material Using the Wire-Arc Additive Manufacturing Process. Metall. Mater. Trans. B Process Metall. Mater. Process. Sci. 47, 763-772 (2016).

21. Shen, C., Pan, Z., Ma, Y., Cuiuri, D. \& Li, H. Fabrication of iron-rich Fe-Al intermetallics using the wire-arc additive manufacturing process. Addit. Manuf. 7, 20-26 (2015).

22. Yamagiwa, K., Watanabe, Y., Fukui, Y. \& Kapranos, P. Novel recycling system of aluminum and iron wastes-in-situ $\mathrm{Al}-\mathrm{Al} 3 \mathrm{Fe}$ functionally graded material manufactured by a centrifugal method. Mater. Trans. 44, 2461-2467 (2003).

23. Fan, J., Thomy, C. \& Vollertsen, F. Effect of thermal cycle on the formation of intermetallic compounds in laser welding of aluminum-steel overlap joints. in Physics Procedia vol. 12 134-141 (Elsevier B.V., 2011).

24. Wang, C. et al. The influence of heat input on microstructure and mechanical properties for dissimilar welding of galvanized steel to 6061 aluminum alloy in a zero-gap lap joint configuration. J. Alloys Compd. 726, 556-566 (2017).

25. Meco, S., Ganguly, S., Williams, S. \& McPherson, N. Effect of laser processing parameters on the formation of intermetallic compounds in Fe-Al dissimilar welding. $J$. Mater. Eng. Perform. 23, 3361-3370 (2014).

26. Elrefaey, A., Gouda, M., Takahashi, M. \& Ikeuchi, K. Characterization of aluminum/steel lap joint by friction stir welding. J. Mater. Eng. Perform. 14, 10-17 (2005).

27. Abbasi, M., Dehghani, M., Guim, H. U. \& Kim, D. I. Investigation of Fe-rich fragments in 
aluminum-steel friction stir welds via simultaneous Transmission Kikuchi Diffraction and EDS. Acta Mater. 117, 262-269 (2016).

28. Das, H., Ghosh, R. N. \& Pal, T. K. Study on the formation and characterization of the intermetallics in friction stir welding of aluminum alloy to coated steel sheet lap joint. in Metallurgical and Materials Transactions A: Physical Metallurgy and Materials Science vol. 45 5098-5106 (Springer Boston, 2014).

29. Haghshenas, M. et al. Friction stir weld assisted diffusion bonding of 5754 aluminum alloy to coated high strength steels. Mater. Des. 55, 442-449 (2014).

30. Movahedi, M. et al. Growth kinetics of Al-Fe intermetallic compounds during annealing treatment of friction stir lap welds. Mater. Charact. 90, 121-126 (2014).

31. Taban, E., Gould, J. E. \& Lippold, J. C. Dissimilar friction welding of 6061-T6 aluminum and AISI 1018 steel: Properties and microstructural characterization. Mater. Des. 31, 2305-2311 (2010).

32. Bozzi, S., Helbert-Etter, A. L., Baudin, T., Criqui, B. \& Kerbiguet, J. G. Intermetallic compounds in Al 6016/IF-steel friction stir spot welds. Mater. Sci. Eng. A 527, 4505-4509 (2010).

33. Wang, K. et al. Investigation of Interfacial Layer for Friction Stir Scribe Welded Aluminum to Steel Joints. J. Manuf. Sci. Eng. 140, (2018).

34. Najafi, A., Movahedi, M. \& Yarandi, A. S. Properties-microstructure relationship in AlFe in situ composite produced by friction stir processing. Proc. Inst. Mech. Eng. Part LJ. Mater. Des. Appl. 233, 1955-1965 (2019).

35. Agudo, L. et al. Intermetallic Fe x Al y -phases in a steel/Al-alloy fusion weld. J. Mater. Sci. 42, 4205-4214 (2007). 
36. Zhang, G., Chen, M., Shi, Y., Huang, J. \& Yang, F. Analysis and modeling of the growth of intermetallic compounds in aluminum-steel joints. RSC Adv. 7, 37797-37805 (2017).

37. Ding, Z. et al. Microstructural evolution and growth behavior of intermetallic compounds at the liquid Al/solid Fe interface by synchrotron X-ray radiography. Mater. Charact. 136, 157-164 (2018).

38. Bouché, K., Barbier, F. \& Coulet, A. Intermetallic compound layer growth between solid iron and molten aluminium. Mater. Sci. Eng. A 249, 167-175 (1998).

39. Bouayad, A., Gerometta, C., Belkebir, A. \& Ambari, A. Kinetic interactions between solid iron and molten aluminium. Mater. Sci. Eng. A 363, 53-61 (2003).

40. Naoi, D. \& Kajihara, M. Growth behavior of Fe2A15 during reactive diffusion between Fe and Al at solid-state temperatures. Mater. Sci. Eng. A 459, 375-382 (2007).

41. Tanaka, Y. \& Kajihara, M. Kinetics of isothermal reactive diffusion between solid Fe and liquid Al. J. Mater. Sci. 45, 5676-5684 (2010).

42. Wang, X., Wood, J. V., Sui, Y. \& Lu, H. Formation of intermetallic compound in ironaluminum alloys. J. Shanghai Univ. (English Ed. 2, 305-310 (1998).

43. Novák, P. et al. On the formation of intermetallics in Fe-Al system - An in situ XRD study. Intermetallics 32, 127-136 (2013).

44. Van Alboom, A. et al. Multi-method identification and characterization of the intermetallic surface layers of hot-dip Al-coated steel: FeAl3 or Fe4Al13 and Fe2Al5 or Fe2Al5+x. Surf. Coatings Technol. 324, 419-428 (2017).

45. Liu, Z.-K. Computational thermodynamics and its applications. Acta Mater. 200, 745-792 (2020).

46. Schmid-Fetzer, R. Phase Diagrams: The Beginning of Wisdom. J. Phase Equilibria 
Diffus. 35, 735-760 (2014).

47. Scheil, E. Bemerkungen zur schichtkristallbildung. Zeitschrift für Met. 34, 70-72 (1942).

48. Gulliver, G. H. The quantitative effect of rapid cooling upon the constitution of binary alloys. J. Inst. Met 9, 120-157 (1913).

49. Moustafa, A. R., Durga, A., Lindwall, G. \& Cordero, Z. C. Scheil ternary projection (STeP) diagrams for designing additively manufactured functionally graded metals. Addit. Manuf. 32, 101008 (2020).

50. Bocklund, B., Bobbio, L. D., Otis, R. A., Beese, A. M. \& Liu, Z.-K. Experimental validation of Scheil-Gulliver simulations for gradient path planning in additively manufactured functionally graded materials. Materialia 11, 100689 (2020).

51. Schaffnit, P., Stallybrass, C., Konrad, J., Stein, F. \& Weinberg, M. A Scheil-Gulliver model dedicated to the solidification of steel. Calphad Comput. Coupling Phase Diagrams Thermochem. 48, 184-188 (2015).

52. Lee, H. M., Yoon, S. W. \& Lee, B.-J. Thermodynamic prediction of interface phases at Cu/solder joints. J. Electron. Mater. 27, 1161-1166 (1998).

53. Zhou, S. H. \& Napolitano, R. E. Energetics of nonequilibrium solidification in Al-Sm. Phys. Rev. B 78, 184111 (2008).

54. Wang, K. et al. Unveiling non-equilibrium metallurgical phases in dissimilar Al-Cu joints processed by vaporizing foil actuator welding. Mater. Des. 186, 108306 (2020).

55. Andersson, J.-O., Helander, T., Höglund, L., Shi, P. \& Sundman, B. Thermo-Calc \&amp; DICTRA, computational tools for materials science. Calphad 26, 273-312 (2002).

56. Du, Y. et al. Diffusion coefficients of some solutes in fcc and liquid Al: Critical evaluation and correlation. Mater. Sci. Eng. A 363, 140-151 (2003). 
57. Helander, T. \& Ågren, J. A phenomenological treatment of diffusion in Al-Fe and Al-Ni alloys having B2-b.c.c. ordered structure. Acta Mater. 47, 1141-1152 (1999).

58. Burkhardt, U., Grin, Y., Ellner, M., Peters, K. \& IUCr. Structure refinement of the ironaluminium phase with the approximate composition Fe2A15. Acta Crystallogr. Sect. B Struct. Sci. 50, 313-316 (1994).

59. Chumak, I., Richter, K. W. \& Ehrenberg, H. Redetermination of iron dialuminide, FeAl 2. Acta Crystallogr. Sect. C Cryst. Struct. Commun. 66, i87-i88 (2010).

60. Lyakhov, A. O., Oganov, A. R., Stokes, H. T. \& Zhu, Q. New developments in evolutionary structure prediction algorithm USPEX. Comput. Phys. Commun. 184, 1172$1182(2013)$.

61. Jain, A. et al. Commentary: The Materials Project: A materials genome approach to accelerating materials innovation. APL Mater. 1, 011002 (2013).

62. Kirklin, S. et al. The Open Quantum Materials Database (OQMD): assessing the accuracy of DFT formation energies. npj Comput. Mater. 1, 15010 (2015).

63. van de Walle, A. et al. Efficient stochastic generation of special quasirandom structures. Calphad 42, 13-18 (2013).

64. Glass, C. W., Oganov, A. R. \& Hansen, N. USPEX - Evolutionary crystal structure prediction. Comput. Phys. Commun. 175, 713-720 (2006).

65. Vinokur, A. I., Hilleke, K. P. \& Fredrickson, D. C. Principles of weakly ordered domains in intermetallics: The cooperative effects of atomic packing and electronics in Fe2Al5. Acta Crystallogr. Sect. A Found. Adv. 75, 297-306 (2019).

66. Tobita, K. et al. Phase stability and thermoelectric properties of semiconductor-like tetragonal FeAl2. Sci. Technol. Adv. Mater. 20, 937-948 (2019). 
67. Gražulis, S. et al. Crystallography Open Database - an open-access collection of crystal structures. J. Appl. Crystallogr. 42, 726-729 (2009).

68. Gražulis, S. et al. Crystallography Open Database (COD): an open-access collection of crystal structures and platform for world-wide collaboration. Nucleic Acids Res. 40, D420-D427 (2012).

69. Choudhary, K. et al. The joint automated repository for various integrated simulations (JARVIS) for data-driven materials design. npj Comput. Mater. 6, 173 (2020).

70. Krajewski, A. M., Siegel, J. W., Xu, J. \& Liu, Z.-K. Extensible Structure-Informed Prediction of Formation Energy with Improved Accuracy and Usability employing Neural Networks. arXiv arXiv:2008.13654 (2020).

71. Shang, S.-L., Wang, Y., Kim, D. \& Liu, Z.-K. First-principles thermodynamics from phonon and Debye model: Application to Ni and Ni3Al. Comput. Mater. Sci. 47, 10401048 (2010).

72. Wang, A. et al. Effects of pressure and vibration on the thermal decomposition of cubic Ti1-xAlxN, Ti1-xZrxN, and Zr1-xAlxN coatings: A first-principles study. J. Mater. Sci. 47, 7621-7627 (2012).

73. Wang, Y., Liu, Z. K. \& Chen, L. Q. Thermodynamic properties of Al, Ni, NiAl, and Ni3Al from first-principles calculations. Acta Mater. 52, 2665-2671 (2004).

74. Kresse, G. et al. Efficient iterative schemes for ab initio total-energy calculations using a plane-wave basis set. Phys. Rev. B 54, 11169-11186 (1996).

75. Kresse, G. \& Joubert, D. From ultrasoft pseudopotentials to the projector augmented-wave method. Phys. Rev. B 59, 1758-1775 (1999).

76. Perdew, J. P., Burke, K. \& Ernzerhof, M. Generalized Gradient Approximation Made 
Simple. Phys. Rev. Lett. 77, 3865-3868 (1996).

77. Methfessel, M. \& Paxton, A. T. High-precision sampling for Brillouin-zone integration in metals. Phys. Rev. B 40, 3616-3621 (1989).

78. Blöchl, P. E., Jepsen, O. \& Andersen, O. K. Improved tetrahedron method for Brillouinzone integrations. Phys. Rev. B 49, 16223-16233 (1994).

79. Wang, Y. et al. A mixed-space approach to first-principles calculations of phonon frequencies for polar materials. J. Phys. Condens. Matter 22, 202201 (2010).

80. Wang, Y., Shang, S.-L., Fang, H., Liu, Z.-K. \& Chen, L.-Q. First-principles calculations of lattice dynamics and thermal properties of polar solids. npj Comput. Mater. 2, 16006 (2016).

81. Shang, S., Wang, Y. \& Liu, Z.-K. First-principles elastic constants of $\alpha$ - and $\theta-\mathrm{A} 12 \mathrm{O} 3$. Appl. Phys. Lett. 90, 101909 (2007).

82. Shang, S. L. et al. First-principles calculations of pure elements: Equations of state and elastic stiffness constants. Comput. Mater. Sci. 48, 813-826 (2010).

83. Hill, R. The Elastic Behaviour of a Crystalline Aggregate. Proc. Phys. Soc. Sect. A 65, 349-354 (1952).

84. Simmons, G. \& Wang, H. Single crystal elastic constants and calculated aggregate properties: A handbook. (M.I.T. Press, 1971).

85. Ranganathan, S. I. \& Ostoja-Starzewski, M. Universal elastic anisotropy index. Phys. Rev. Lett. 101, 055504 (2008).

86. Hillert, M. Phase equilibria, phase diagrams and phase transformations: Their thermodynamic basis. (Cambridge University Press, 2008).

87. Otis, R. \& Liu, Z.-K. pycalphad: CALPHAD-based Computational Thermodynamics in 
Python. J. Open Res. Softw. 5, 1 (2017).

88. Wolverton, C. \& Ozoliņš, V. Entropically Favored Ordering: The Metallurgy of A12Cu Revisited. Phys. Rev. Lett. 86, 5518-5521 (2001).

89. Shang, S.-L., Wang, Y., Du, Y. \& Liu, Z.-K. Entropy favored ordering: Phase stability of Ni3Pt revisited by first-principles. Intermetallics 18, 961-964 (2010).

90. Tobita, K. et al. High-pressure synthesis of tetragonal iron aluminide FeA12. Scr. Mater. 141, 107-110 (2017).

91. Stein, F., Vogel, S. C., Eumann, M. \& Palm, M. Determination of the crystal structure of the $\varepsilon$ phase in the Fe-Al system by high-temperature neutron diffraction. Intermetallics $\mathbf{1 8}$, $150-156(2010)$.

92. Lindwall, G. et al. Simulation of TTT Curves for Additively Manufactured Inconel 625. Metall. Mater. Trans. A 50, 457-467 (2019).

93. Okamoto, N. L., Okumura, J., Higashi, M. \& Inui, H. Crystal structure of ๆ'-Fe3A18; lowtemperature phase of $\eta-\mathrm{Fe} 2 \mathrm{Al} 5$ accompanied by an ordered arrangement of $\mathrm{Al}$ atoms of full occupancy in the c-axis chain sites. Acta Mater. 129, 290-299 (2017). 


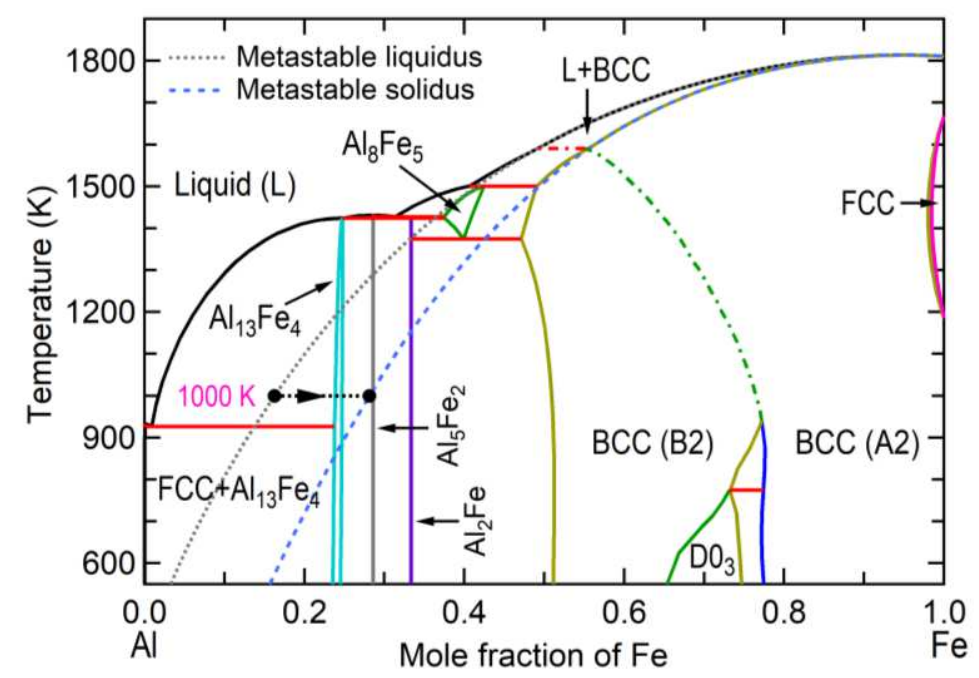

Figure 1. Calculated Al-Fe phase diagram based on CALPHAD modeling by Sundman et al. ${ }^{9}$. The metastable liquidus and solidus lines are plotted to analyze the formation of non-equilibrium phases from the supersaturated solution phase; and one example at $1000 \mathrm{~K}$ is shown for phase equilibrium from the supercooled liquid with composition $x_{\mathrm{Fe}}=0.163$ to the supersaturated BCC phase with $x_{\mathrm{Fe}}=0.218$.

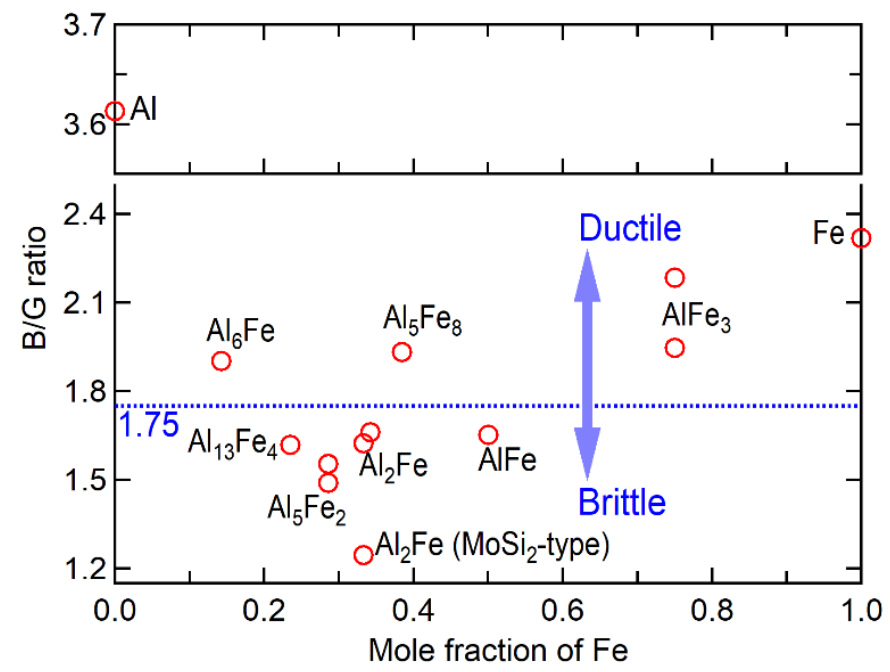

Figure 2. Calculated bulk modulus versus shear modulus $(B / G)$ ratios of Al-Fe IMCs based on the present DFT calculations; see details in Table S 3. Note that the Pugh's criterion ${ }^{11}$ of 1.75 is a rough value to separate the ductile and brittle materials as discussed in the authors' responses to Reviewers in ${ }^{12}$. 


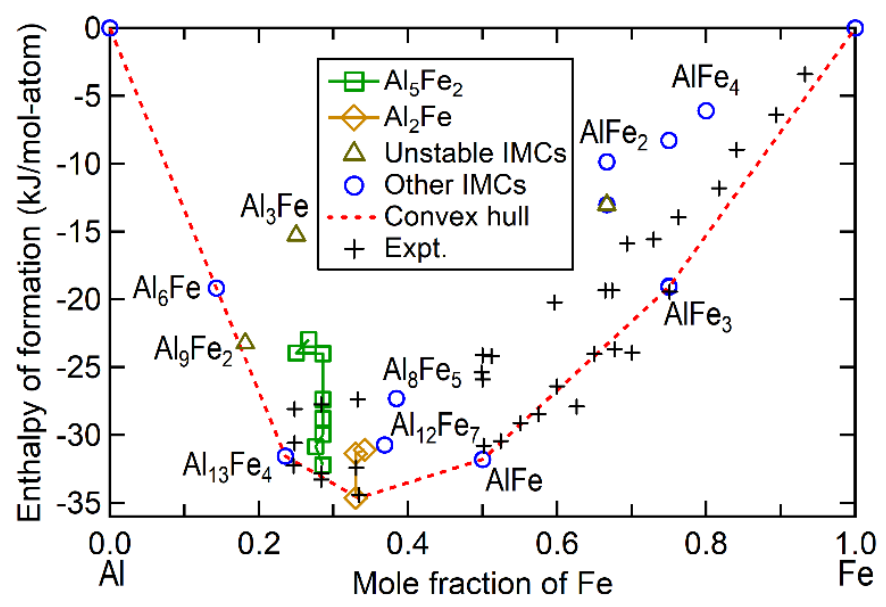

Figure 3. Predicted enthalpies of formation $\left(\Delta \mathrm{H}_{0}\right)$ at $T=0 \mathrm{~K}$ and $P=0 \mathrm{GPa}$ for Al-Fe IMCs by the present DFT calculations (see structural details and $\Delta \mathrm{H}_{0}$ values in Table $\mathrm{S} 1$ ). Note that the convex hull was plotted using the DFT results, the unstable IMCs were judged by imaginary phonon modes, and the experimental data (Expt.) were collected by Sundman et al. ${ }^{9}$. 


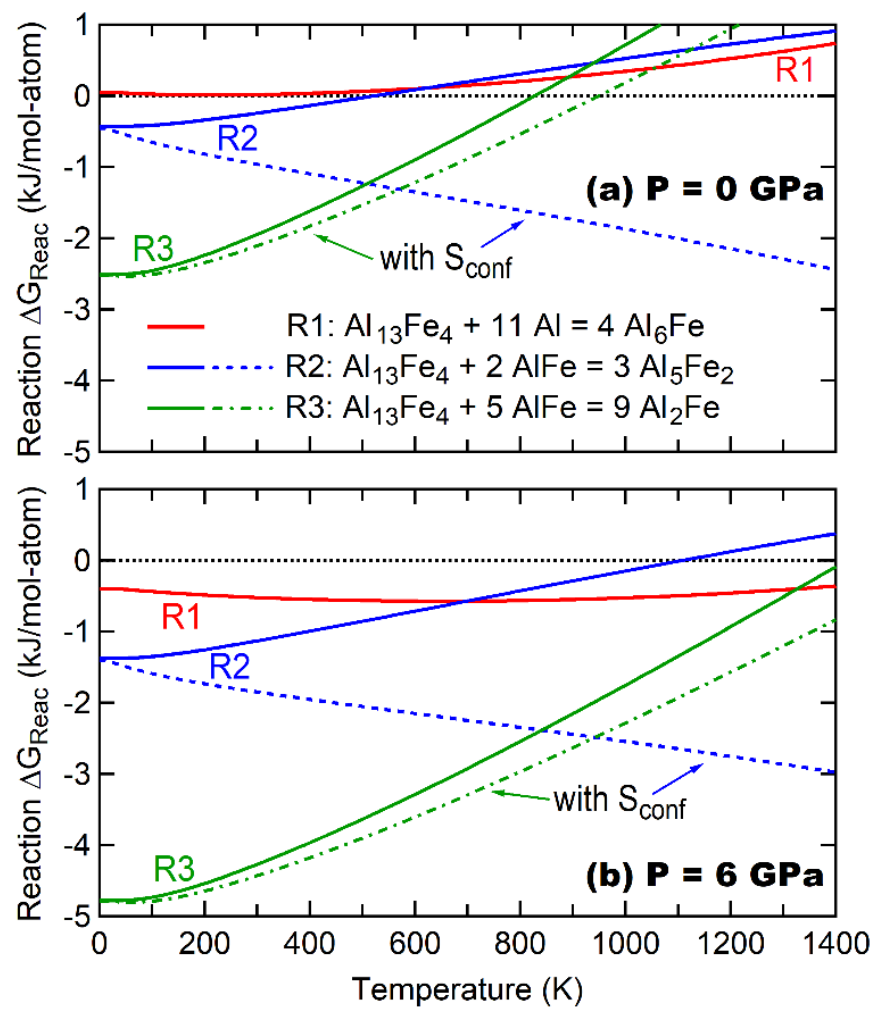

Figure 4. Reaction Gibbs energies ( $\Delta \mathrm{G}_{\text {reac's }}$ ) under external pressure $P=0 \mathrm{GPa}$ (a) and $6 \mathrm{GPa}$ (b) with and without considering the ideal configurational entropies ( $\mathrm{S}_{\text {conf }} \mathrm{s}$ ) of $\mathrm{Al}_{5} \mathrm{Fe}_{2}$ and $\mathrm{Al}_{2} \mathrm{Fe}$, respectively; see Eq. 4 and Eq. 5.

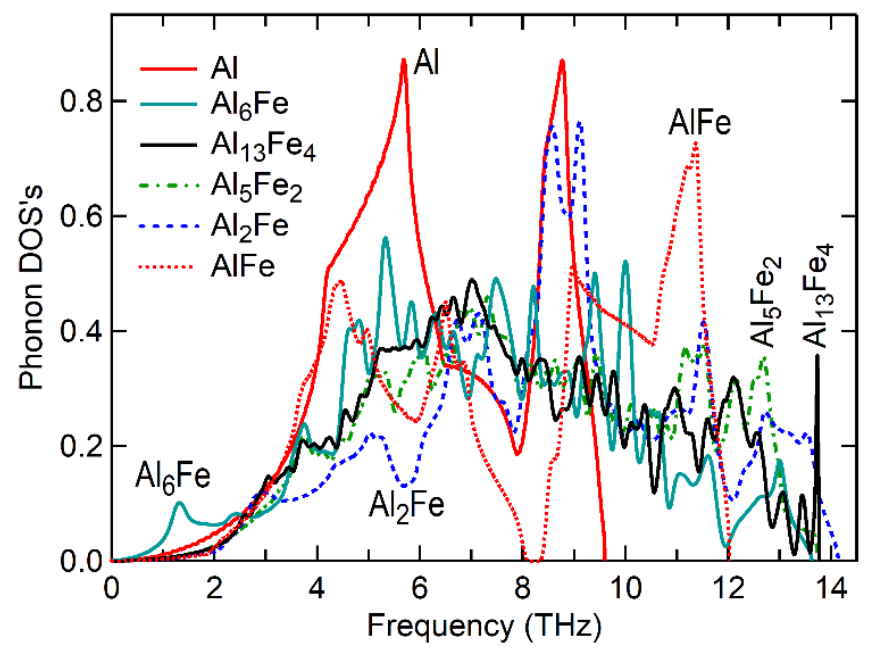

Figure 5. Calculated phonon densities of states (DOS's) of fcc $\mathrm{Al}$ and the selected $\mathrm{IMCs}_{\mathrm{MC}} \mathrm{Al}_{6} \mathrm{Fe}$, $\mathrm{Al}_{13} \mathrm{Fe}_{4}, \mathrm{Al}_{5} \mathrm{Fe}_{2}$ (predicted by USPEX), the $\mathrm{MoSi}_{2}$-type $\mathrm{Al}_{2} \mathrm{Fe}$, and $\mathrm{AlFe}$ (the $\mathrm{B} 2$ phase). Note that all phonon DOS's have the same integral value. 


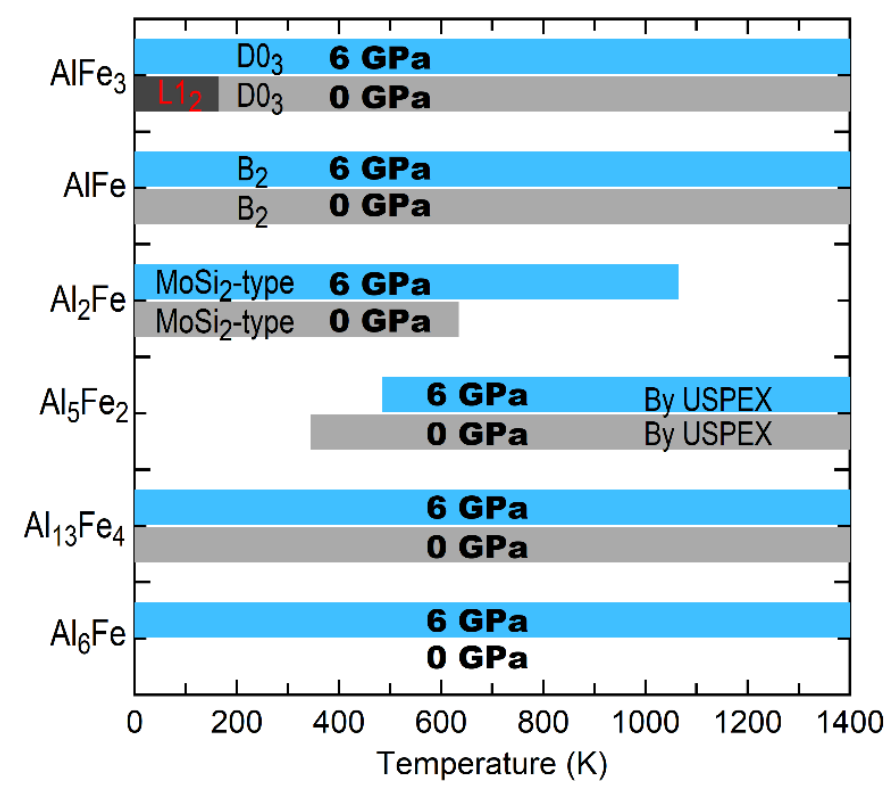

Figure 6. Phase stability (on the convex hull) of Al-Fe IMCs under external pressures of 0 and 6 $\mathrm{GPa}$ as a function of temperature (shown in the shaded regions) based on the present DFT calculations using Eq. 3.

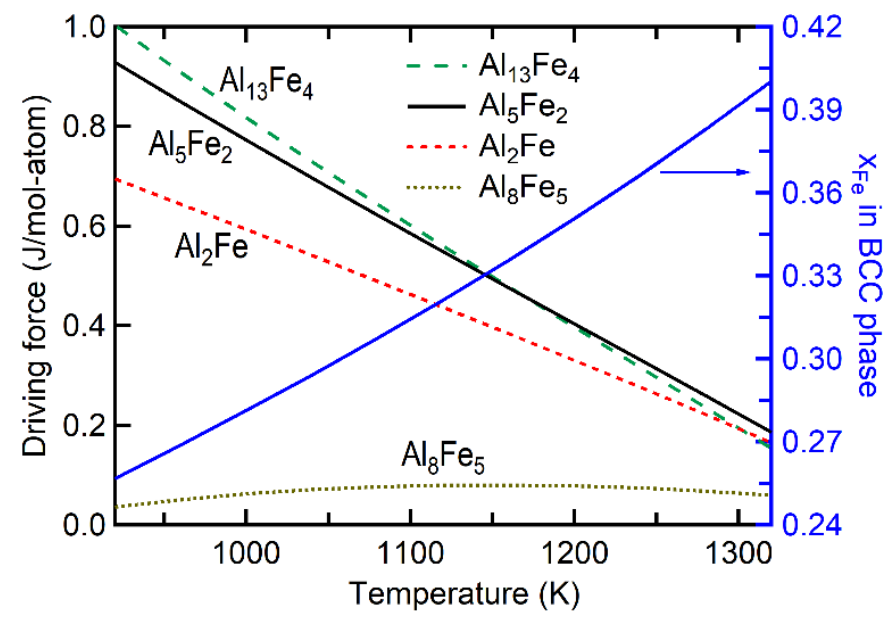

Figure 7. Thermodynamic driving forces the Al-Fe IMCs as a function of temperature together with the mole fraction of $\mathrm{Fe}\left(x_{\mathrm{Fe}}\right)$ along the metastable BCC phase in Figure 1. Here, the used AlFe thermodynamic properties were modelled by Sundman et al. ${ }^{9}$. 


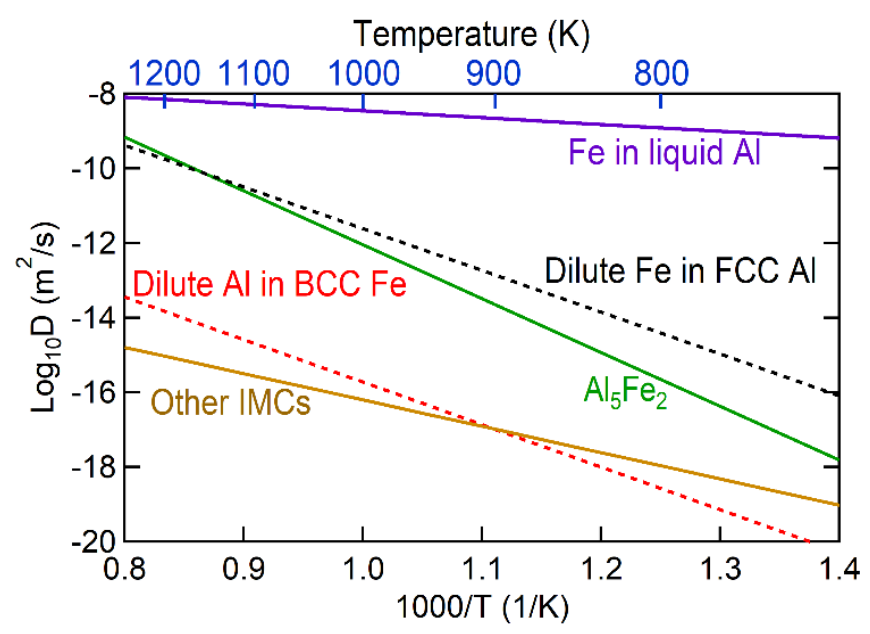

Figure 8. Diffusion coefficients of $\mathrm{Fe}$ in liquid $\mathrm{Al}^{56}$, dilute $\mathrm{Fe}$ in $\mathrm{FCC} \mathrm{Al}^{56}$, dilute $\mathrm{Al}$ in $\mathrm{BCC} \mathrm{Fe}$ ${ }^{57}$, and the elements in $\mathrm{Al}_{5} \mathrm{Fe}_{2}$ and other IMCs $\left(\mathrm{AlFe}, \mathrm{Al}_{2} \mathrm{Fe} \text {, and } \mathrm{Al}_{13} \mathrm{Fe}_{4}\right)^{40}$.

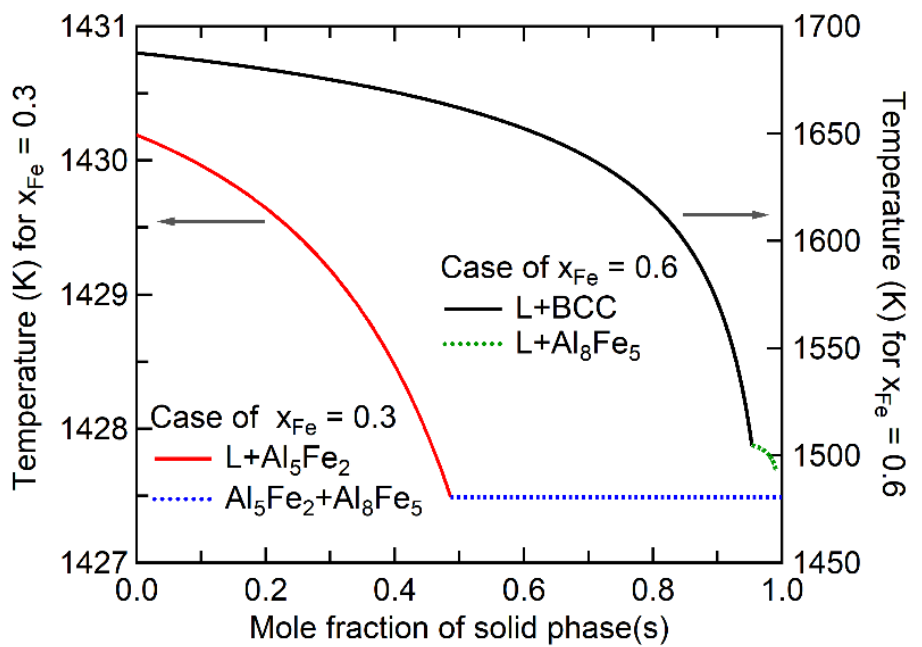

Figure 9. Calculated mole fractions of solid phases with $x_{\mathrm{Fe}}=0.3$ and 0.6 based on Scheil simulations using thermodynamic descripiton modelled by Sundman et al. ${ }^{9}$. 


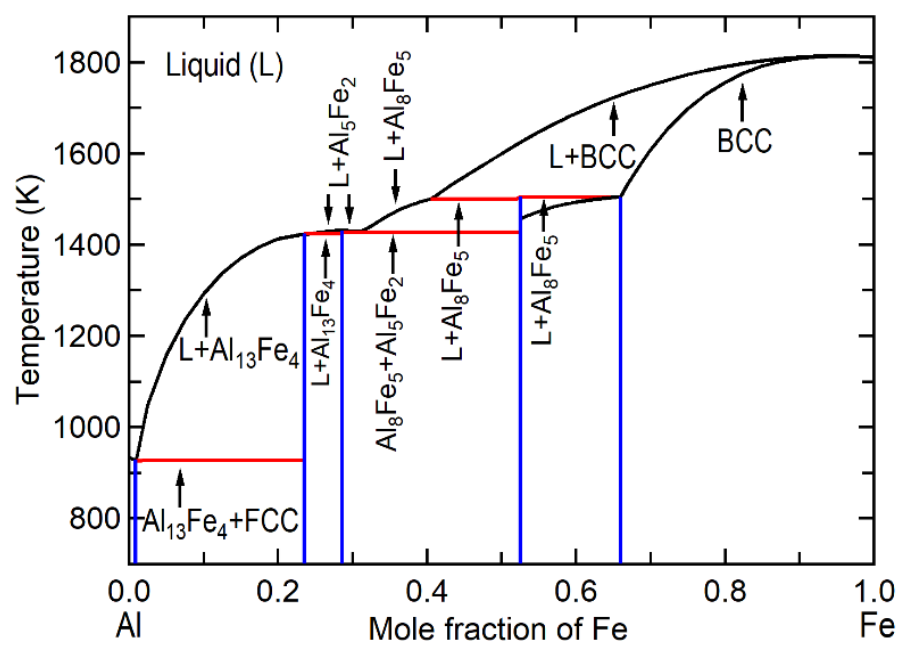

Figure 10. Predicted Al-Fe non-equilibrium phase diagram by Scheil simulations uisng the modelled data by Sundman et al. ${ }^{9}$, showing the forming temperatures for the phases indicated by the lines. Note that the lever rule cannot be used to determine phase fractions (see Figure 9 for two examples).

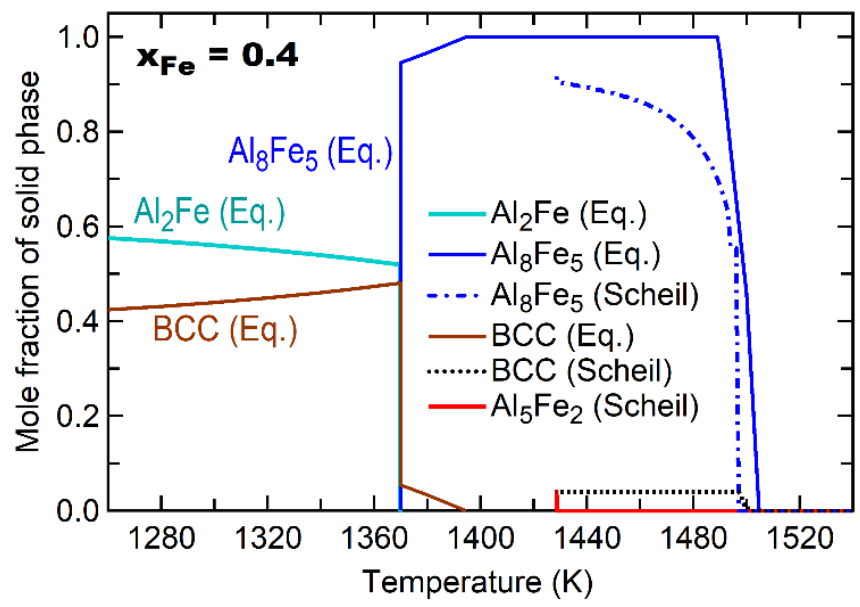

Figure 11. Calculated mole fracitons of solid phases with $x_{\mathrm{Fe}}=0.4$ based on Scheil simulations and equilibrium (Eq.) calculations using the modelled data by Sundman et al. ${ }^{9}$. 
Table 1. Experimentally observed Al-Fe IMCs in various processes in the literature. Note that the compositions quoted in this table are in wt.\% unless otherwise stated.

\begin{tabular}{|c|c|c|c|}
\hline \#, Ref. & Materials & Methods & Observed Al-Fe IMCs \\
\hline $1^{10}$ & $\begin{array}{l}\text { Sheet ingots of } \mathrm{Al} \text { alloys: } \\
1050,-1100 \text {, and }-5005\end{array}$ & Direct-chill casting & $\begin{array}{l}\mathrm{Al}_{13} \mathrm{Fe}_{4} \text { with cooling rate }<3 \mathrm{~K} / \mathrm{s} ; \mathrm{Al}_{6} \mathrm{Fe} \text { with } \\
\text { cooling rate from } 1-3 \text { to } 10-20 \mathrm{~K} / \mathrm{s} ; \text { and } \mathrm{Al}_{\mathrm{m}} \mathrm{Fe}(4 \leq \\
\mathrm{m} \leq 4.4) \text { with cooling rate }>20 \mathrm{~K} / \mathrm{s}\end{array}$ \\
\hline $2^{13}$ & $\begin{array}{l}\text { Al-5Mg- } x \text { Fe- } 0.6 \mathrm{Mn}(x= \\
0.1 \sim 2 \text { wt. } \%)\end{array}$ & $\begin{array}{l}\text { High pressure die casting at } \\
720^{\circ} \mathrm{C}\end{array}$ & $\mathrm{Al}_{6}(\mathrm{Fe}, \mathrm{Mn})$ and $\mathrm{Al}_{13}(\mathrm{Fe}, \mathrm{Mn})_{4}{ }^{\mathrm{a}}$ \\
\hline $3^{14}$ & Al-3Fe alloy & $\begin{array}{l}\text { Equal channel angular } \\
\text { extrusion at room temperature }\end{array}$ & $\mathrm{Al}_{6} \mathrm{Fe}$ \\
\hline $4^{15}$ & $\begin{array}{l}\text { Al alloy } 5 \mathrm{~A} 06 \text { and } \\
\text { SUS321 steel sheets }\end{array}$ & $\begin{array}{l}\text { Tungsten inert gas welding- } \\
\text { brazing with Al filler }\end{array}$ & $\begin{array}{l}\mathrm{Al}_{6} \mathrm{Fe} \text { in welded seam with Nocolok flux; and } \\
\mathrm{Al}_{13} \mathrm{Fe}_{4} \text { in the IMC layer }\end{array}$ \\
\hline $5^{16}$ & $\begin{array}{l}\text { Al-2.5wt.\% Fe alloy } \\
\text { powders }\end{array}$ & $\begin{array}{l}\text { Laser powder bed fusion } \\
\text { (LPBF) }\end{array}$ & $\begin{array}{l}\mathrm{Al}_{13} \mathrm{Fe}_{4} \text { (reduced in the LPBF samples compared to } \\
\text { ingots) and } \mathrm{Al}_{6} \mathrm{Fe}\end{array}$ \\
\hline $6^{17}$ & $\mathrm{Al}$ and $\mathrm{Fe}$ powders & Layer by layer laser cladding & $\begin{array}{l}\mathrm{Al}_{2} \mathrm{Fe} \text { (with } 34 \sim 52 \text { at. } \% \mathrm{Al} \text { cases); and } \mathrm{Al}_{5} \mathrm{Fe}_{2} \text { and } \\
\mathrm{Al}_{13} \mathrm{Fe}_{4} \text { (with }>52 \text { at. } \% \mathrm{Al} \text { cases) }\end{array}$ \\
\hline $7^{18}$ & $\mathrm{Al}$ and $\mathrm{Fe}$ powders & $\begin{array}{l}\text { Direct energy deposition } \\
\text { (DED) type process }\end{array}$ & $\begin{array}{l}\mathrm{AlFe}_{3} \text { (for composition } \mathrm{Fe}-28 \mathrm{Al} \text { ); } \mathrm{AlFe}_{3}+\mathrm{AlFe} \text { (for } \\
\mathrm{Fe}-36 \mathrm{Al} \text { ); and } \mathrm{AlFe} \text { (for } \mathrm{Fe}-50 \mathrm{Al} \text { ) }\end{array}$ \\
\hline $8^{19}$ & $\mathrm{Fe}-28 \mathrm{Al}$ and $\mathrm{Al}$ powders & $\begin{array}{l}\text { Laser metal deposition for } \\
\text { graded } \mathrm{Fe}-\mathrm{Al} / \text { steel samples } \\
\text { and heat treated at } 700{ }^{\circ} \mathrm{C}\end{array}$ & $\begin{array}{l}\mathrm{AlFe} \text { and } \mathrm{Al}_{2} \mathrm{Fe} \text { (cracks originated in } \mathrm{Al} \text {-rich part) } \\
\text { followed by } \mathrm{Al} \text {-rich } \mathrm{AlFe} \text { below }\end{array}$ \\
\hline $9^{20}$ & $\mathrm{Al}$ and $\mathrm{Fe}$ wires & $\begin{array}{l}\text { Wire-arc AM (WAAM) for } \\
\text { Fe-AlFe functionally graded } \\
\text { material (FGM) }\end{array}$ & $\mathrm{AlFe}_{3}$ and $\mathrm{AlFe}$ \\
\hline $10^{21}$ & $\mathrm{Al}$ and $\mathrm{Fe}$ wires & $\begin{array}{l}\text { WAAM to fabricate Fe-rich } \\
\text { IMC }(25 \text { at. } \% \mathrm{Al})\end{array}$ & $\mathrm{AlFe}_{3}$ \\
\hline $11^{22}$ & $\begin{array}{l}\text { Pure Al with } \mathrm{Al}-10 \text { wt.\% } \\
\text { Fe }\end{array}$ & $\begin{array}{l}\text { Vacuum centrifugal method } \\
\text { to make } \mathrm{Al}-\mathrm{Al}_{13} \mathrm{Fe}_{4} \mathrm{FGM}\end{array}$ & $\mathrm{Al}_{13} \mathrm{Fe}_{4}$ \\
\hline $12^{43}$ & $\begin{array}{l}\text { Compressed mixture of } \\
\mathrm{Al} \text { and Fe powders }\end{array}$ & $\begin{array}{l}\text { High-temperature reactive } \\
\text { sintering }\left(800 \text { and } 900{ }^{\circ} \mathrm{C}\right)\end{array}$ & $\mathrm{Al}_{5} \mathrm{Fe}_{2}$ and $\mathrm{Al}_{2} \mathrm{Fe}$; and $\mathrm{AlFe}$ (long-term annealing) \\
\hline $13^{23}$ & Al-steel overlap joints & Laser welding (up to $1200^{\circ} \mathrm{C}$ ) & $\mathrm{Al}_{5} \mathrm{Fe}_{2}$ (assuming diffusion from $\mathrm{Fe}$ to $\mathrm{Al}$ only) \\
\hline $14^{24}$ & $\begin{array}{l}\text { Al alloy 6061-T6 and } \\
\text { galvanized steel DP590 }\end{array}$ & Laser welding without filler & $\begin{array}{l}\mathrm{Al}_{13} \mathrm{Fe}_{4} \text { and } \mathrm{Al}_{5} \mathrm{Fe}_{2} \text { with linear energy density of } 162 \\
\mathrm{~J} / \mathrm{mm} ; \mathrm{Al}_{13} \mathrm{Fe}_{4}, \mathrm{Al}_{5} \mathrm{Fe}_{2} \text {, and } \mathrm{AlFe} \text { with } 309 \mathrm{~J} / \mathrm{mm}\end{array}$ \\
\hline $15^{25}$ & $\begin{array}{l}\text { Al alloy } 5083 \text { and low } \\
\text { alloy steel (XF350) plates }\end{array}$ & $\begin{array}{l}\text { Fiber laser welding with } 8 \mathrm{~kW} \\
\text { of max power }\end{array}$ & $\mathrm{Al}_{5} \mathrm{Fe}_{2}$ near steel (main) and $\mathrm{Al}_{13} \mathrm{Fe}_{4}$ near $\mathrm{Al}$ \\
\hline $16^{26}$ & $\begin{array}{l}\text { Pure } \mathrm{Al}(1100) \text { and low } \\
\text { carbon steel }\end{array}$ & Friction stir welding & $\mathrm{Al}_{5} \mathrm{Fe}_{2}$ and $\mathrm{Al}_{13} \mathrm{Fe}_{4}$ \\
\hline $17^{27}$ & $\begin{array}{l}\mathrm{Al} \text { alloy (5186) and low } \\
\text { carbon steel }\end{array}$ & Friction stir welding & $\begin{array}{l}\mathrm{Al}_{5} \mathrm{Fe}_{2} \text { (adjacent to } \mathrm{Fe} \text { ) and } \mathrm{Al}_{13} \mathrm{Fe}_{4} \text { (adjacent to } \mathrm{Al} \text {, } \\
\text { facilitated by } \mathrm{Fe} \text { diffusion) }\end{array}$ \\
\hline $18^{28}$ & $\begin{array}{l}\text { Al sheet (6061) and } \\
\text { galvannealed steel sheet }\end{array}$ & Friction stir welding & $\begin{array}{l}\mathrm{Al}_{13} \mathrm{Fe}_{4} \text { (large size, diffusion induced) and } \mathrm{AlFe}_{3} \\
\text { (small size) }\end{array}$ \\
\hline $19^{29}$ & $\begin{array}{l}\text { Al alloy } 5754 \text { with coated } \\
\text { DP600 or } 22 \mathrm{MnB} 5 \text { steel }\end{array}$ & $\begin{array}{l}\text { Diffusion bonding by friction } \\
\text { stir welding }\end{array}$ & $\begin{array}{l}\mathrm{Al}_{5} \mathrm{Fe}_{2} \text { in low welding speeds }(16 \mathrm{~mm} / \mathrm{min}) \text { and } \\
\mathrm{AlFe} \text { in } 45 \mathrm{~mm} / \mathrm{min}\end{array}$ \\
\hline $20^{30}$ & $\begin{array}{l}\mathrm{Al} \text { alloy } 5083 \text { and steel }(< \\
0.1 \text { wt.\% C) sheets }\end{array}$ & $\begin{array}{l}\text { Annealing of friction stir lap } \\
\text { welds }\end{array}$ & $\begin{array}{l}\mathrm{Al}_{5} \mathrm{Fe}_{2} \text { (major) and } \mathrm{Al}_{13} \mathrm{Fe}_{4} \text { annealed at } 673 \mathrm{~K} \text { for } \\
180 \mathrm{~min}\end{array}$ \\
\hline $21^{31}$ & $\begin{array}{l}\text { Al alloy 6061-T6 and } \\
\text { AISI } 1018 \text { steel }\end{array}$ & Friction welding & $\mathrm{Al}_{5} \mathrm{Fe}_{2}$ and $\mathrm{AlFe}$ (suggested based on compositions) \\
\hline $22^{32}$ & $\begin{array}{l}\text { Al sheet (6016) and } \\
\text { galvanized IF-steel sheet }\end{array}$ & Friction stir spot welding & $\mathrm{Al}_{13} \mathrm{Fe}_{4}, \mathrm{Al}_{5} \mathrm{Fe}_{2}$, and $\mathrm{Al}_{2} \mathrm{Fe}$ \\
\hline $23^{33}$ & $\begin{array}{l}\text { Al alloy (surfalex } 6 \mathrm{~s} \text { ) and } \\
\text { ultrahigh strength steel }\end{array}$ & Friction stir scribe welding & $\begin{array}{l}\mathrm{Al}_{5} \mathrm{Fe}_{2} \text { (in the middle) or } \mathrm{Al}_{13} \mathrm{Fe}_{4} \text { with } \mathrm{Fe} / \mathrm{Al} \text { solid } \\
\text { solution depending on the weld regions }\end{array}$ \\
\hline $24^{34}$ & $\begin{array}{l}\text { Al alloy (1050) sheets } \\
\text { and Fe particles }\end{array}$ & Friction stir processing & $\begin{array}{l}\mathrm{Al}_{5} \mathrm{Fe}_{2} \text { close to } \mathrm{Fe} \text { particle; and } \mathrm{Al}_{13} \mathrm{Fe}_{4} \text { close to } \mathrm{Al} \\
\text { matrix }\end{array}$ \\
\hline $25^{35}$ & $\begin{array}{l}\text { Al sheet }(6061 \mathrm{~T} 4) \text { and } \\
\text { coated steel sheet }\end{array}$ & $\begin{array}{l}\text { Cold metal transfer fusion } \\
\text { welding }\end{array}$ & $\begin{array}{l}\mathrm{Al}_{13} \mathrm{Fe}_{4} \text { (at the interface to } \mathrm{Al} \text { ) and } \mathrm{Al}_{5} \mathrm{Fe}_{2} \text { (tongue- } \\
\text { like, extended into steel) }\end{array}$ \\
\hline
\end{tabular}




\begin{tabular}{|c|c|c|c|}
\hline $26^{36}$ & $\begin{array}{l}\mathrm{Al} \text { alloy wire (ER5356) } \\
\text { and } \mathrm{Zn} \text {-coated steel }\end{array}$ & $\begin{array}{l}\text { Double electrode gas } \\
\text { metal arc welding }\end{array}$ & $\mathrm{Al}_{5} \mathrm{Fe}_{2}$ (major) and $\mathrm{Al}_{13} \mathrm{Fe}_{4}$ \\
\hline $27^{37}$ & Pure $\mathrm{Al}$ and $\mathrm{Fe}$ & $\begin{array}{l}\text { Solid } \mathrm{Fe} \text { in liquid } \mathrm{Al} \text { at } 850 \\
{ }^{\circ} \mathrm{C} \text { for } 0.6 \mathrm{~h}\end{array}$ & $\mathrm{Al}_{5} \mathrm{Fe}_{2}$ layer with needle-like or flake $\mathrm{Al}_{13} \mathrm{Fe}_{4}$ \\
\hline $28^{38}$ & Pure $\mathrm{Al}$ and $\mathrm{Fe}$ & $\begin{array}{l}\text { Immersion tests of solid Fe } \\
\text { and liquid } \mathrm{Al}\left(700 \sim 900{ }^{\circ} \mathrm{C}\right)\end{array}$ & $\mathrm{Al}_{5} \mathrm{Fe}_{2}$ (adjacent to $\left.\mathrm{Fe}\right)$ and $\mathrm{Al}_{13} \mathrm{Fe}_{4}($ adjacent to $\mathrm{Al})$ \\
\hline $29^{39}$ & Pure $\mathrm{Al}$ and $\mathrm{Fe}$ & $\begin{array}{l}\text { Immersion tests of solid Fe } \\
\text { and liquid } \mathrm{Al}\left(700 \sim 900{ }^{\circ} \mathrm{C}\right)\end{array}$ & $\mathrm{Al}_{5} \mathrm{Fe}_{2}$ and $\mathrm{Al}_{13} \mathrm{Fe}_{4}$ \\
\hline $30^{40}$ & $\begin{array}{l}\text { Pure Al plate and pure Fe } \\
\text { sheet }\end{array}$ & Diffusion couples & $\begin{array}{l}\mathrm{Al}_{5} \mathrm{Fe}_{2}\left(\text { at } 873 \mathrm{~K} \text { for } 9 \mathrm{~h} \text { ) and } \mathrm{Al}_{13} \mathrm{Fe}_{4} \text { (at } 913 \mathrm{~K} \text { for }\right. \\
528 \mathrm{~h} \text { ) }\end{array}$ \\
\hline $31^{41}$ & $\begin{array}{l}\text { Pure } \mathrm{Al} \text { and } \mathrm{Fe} \text { rods } \\
\text { (diffusion couples) }\end{array}$ & $\begin{array}{l}\mathrm{Al} \text { and } \mathrm{Fe} \text { by isothermal } \\
\text { bonding and then annealed at } \\
973-1073 \mathrm{~K}\end{array}$ & $\begin{array}{l}\mathrm{Al}_{5} \mathrm{Fe}_{2} \text { (major, tongue-like) close to } \mathrm{Fe} \text { and } \mathrm{Al}_{13} \mathrm{Fe}_{4} \\
\text { close to } \mathrm{Al}\end{array}$ \\
\hline $32^{42}$ & Al-Fe diffusion couples & Riveting $\mathrm{Al}$ rod into $\mathrm{Fe}$ plate & $\begin{array}{l}\mathrm{Al}_{13} \mathrm{Fe}_{4} \text { formed in } \mathrm{Fe} \text { side at } 600{ }^{\circ} \mathrm{C} \text { ( } \mathrm{Al} \text { diffuses to } \\
\mathrm{Fe} \text { ) and } \mathrm{Al}_{5} \mathrm{Fe}_{2} \text { formed in both } \mathrm{Al} \text { and } \mathrm{Fe} \text { sides }>700 \\
{ }^{\circ} \mathrm{C} \text { (due to } \mathrm{Fe} \text { and } \mathrm{Al} \text { interdiffusion) }\end{array}$ \\
\hline $33^{44}$ & Hot-dip Al-coated steel & $\begin{array}{l}\text { Aluminized steel at } 800^{\circ} \mathrm{C} \text { for } \\
60 \mathrm{~s} \text {, then } 680^{\circ} \mathrm{C} \text { for } 60 \mathrm{~s}\end{array}$ & $\begin{array}{l}\mathrm{Al}_{13} \mathrm{Fe}_{4} \text { just beneath } \mathrm{Al} \text { cover layer and } \mathrm{Al}_{5} \mathrm{Fe}_{2} \text { just } \\
\text { underneath steel }\end{array}$ \\
\hline
\end{tabular}

${ }^{a}$ Addition of Mn promotes the formation of $\mathrm{Al}_{6}(\mathrm{Fe}, \mathrm{Mn})$.

Table 2. Summary of phase stability of key Al-Fe IMCs with respect to pressure $(P)$ and temperature $(T)$ shown in Figure 1, Figure 3, and Figure 6 (or not shown); together with their ductility/brittleness according to Pugh's criterion ${ }^{11,12}$ as shown in Figure 2.

\begin{tabular}{|c|c|c|c|}
\hline $\mathrm{Al}-\mathrm{Fe}$ IMCs ${ }^{\mathrm{a}}$ & Ductility & $P$-favored? & $T$-favored? \\
\hline $\mathrm{Al}_{6} \mathrm{Fe}$ & Ductile & Yes & Not, or less effect \\
\hline $\mathrm{Al}_{13} \mathrm{Fe}_{4}\left(\theta, \mathrm{Al}_{3} \mathrm{Fe}^{9}\right)$ & Slightly brittle & Always on convex hull ${ }^{\mathrm{b}}$ & Always on convex hull ${ }^{b}$ \\
\hline $\mathrm{Al}_{5} \mathrm{Fe}_{2}\left(\eta, \mathrm{Al}_{8} \mathrm{Fe}_{3}{ }^{93}\right)$ & Brittle & Not, or less effect & Yes \\
\hline $\mathrm{Al}_{2} \mathrm{Fe}\left(\mathrm{MoSi}_{2}\right.$-type) & Brittle & Yes, and strong & Not \\
\hline $\mathrm{Al}_{8} \mathrm{Fe}_{5}\left(\mathrm{D} 8_{2}, \varepsilon^{9}\right)$ & Ductile & Less effect & Less effect \\
\hline $\mathrm{AlFe}\left(\mathrm{B}_{2}\right)$ & Slightly brittle & Always on convex hull ${ }^{b}$ & Always on convex hull ${ }^{b}$ \\
\hline $\mathrm{AlFe}_{3}\left(\mathrm{D} 0_{3}\right)$ & Ductile & Yes & Yes \\
\hline
\end{tabular}

${ }^{a}$ Names used in the present work together with the names in the parentheses used in the literature.

b These IMCs are always stable and on the convex hull in the present $P$ and $T$ of studied. 


\section{Supplementary Files}

This is a list of supplementary files associated with this preprint. Click to download.

- ShunliAIFelMCsSlonlyv6.docx 